\title{
CAUSTIC-SIDE SOLVENT-EXTRACTION MODELING FOR HANFORD INTERIM PRETREATMENT SYSTEM
}

\section{June 2008}

Prepared by

Bruce A. Moyer

Joseph F. Birdwell, Jr.

Latitia H. Delmau

Joanna McFarlane 


\section{DOCUMENT AVAILABILITY}

Reports produced after January 1, 1996, are generally available free via the U.S. Department of Energy (DOE) Information Bridge:

Web site: http://www.osti.gov/bridge

Reports produced before January 1, 1996, may be purchased by members of the public from the following source:

National Technical Information Service

5285 Port Royal Road

Springfield, VA 22161

Telephone: 703-605-6000 (1-800-553-6847)

TDD: $703-487-4639$

Fax: 703-605-6900

E-mail: info@ntis.fedworld.gov

Web site: $\mathrm{http}: / /$ www.ntis.gov/support/ordernowabout.htm

Reports are available to DOE employees, DOE contractors, Energy Technology Data Exchange (ETDE) representatives, and International Nuclear Information System (INIS) representatives from the following source:

Office of Scientific and Technical Information

P.O. Box 62

Oak Ridge, TN 37831

Telephone: $865-576-8401$

Fax: 865-576-5728

E-mail: reports@adonis.osti.gov

Web site: http://www.osti.gov/contact.html

This report was prepared as an account of work sponsored by an agency of the

United States Government. Neither the United States government nor any agency

thereof, nor any of their employees, makes any warranty, express or implied, or

assumes any legal liability or responsibility for the accuracy, completeness, or

usefulness of any information, apparatus, product, or process disclosed, or represents

that its use would not infringe privately owned rights. Reference herein to any

specific commercial product, process, or service by trade name, trademark,

manufacturer, or otherwise, does not necessarily constitute or imply its endorsement,

recommendation, or favoring by the United States Government or any agency

thereof. The views and opinions of authors expressed herein do not necessarily state

or reflect those of the United States Government or any agency thereof. 
ORNL/TM-2008/073

\title{
CAUSTIC-SIDE SOLVENT-EXTRACTION MODELING FOR HANFORD INTERIM PRETREATMENT SYSTEM
}

Bruce A. Moyer, Joseph F. Birdwell, Jr., Lætitia H. Delmau, and Joanna McFarlane

Date Published: June 2008

\author{
Prepared by \\ OAK RIDGE NATIONAL LABORATORY \\ P.O. Box 2008 \\ Oak Ridge, Tennessee 37831-6285 \\ managed by \\ UT-Battelle, LLC \\ for the \\ U.S. DEPARTMENT OF ENERGY \\ under contract DE-AC05-00OR22725
}


Page intentionally left blank. 


\section{CONTENTS}

\section{Page}

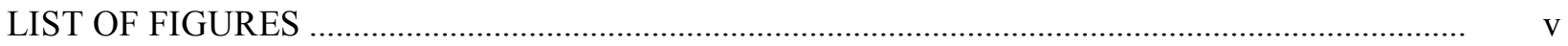

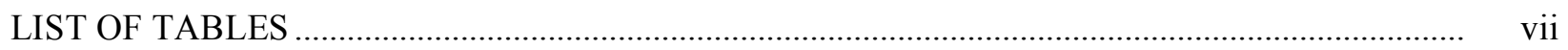

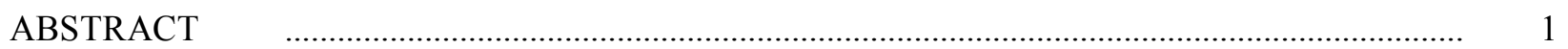

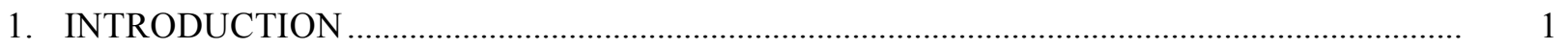

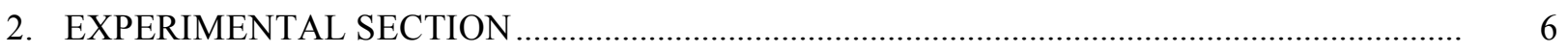

2.1 CHEMICALS, WASTE SIMULANTS, AND SOLVENTS …................................................ 6

2.2 GENERAL SOLVENT-EXTRACTION AND COUNTING PROCEDURE ......................... 8

2.3 PHYSICAL-PROPERTY DETERMINATIONS ............................................................... 9

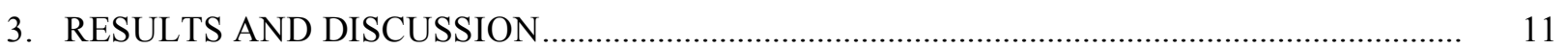

3.1 PREDICTION OF CESIUM DISTRIBUTION RATIOS USING CSSX MODEL............... 11

3.2 EXPERIMENTAL DISTRIBUTION RESULTS .................................................................. 14

3.2.1 Tests with the Current CSSX Solvent ...................................................................... 14

3.2.2 Batch Performance of Alternative CSSX Solvents and Improved Stripping Method 15

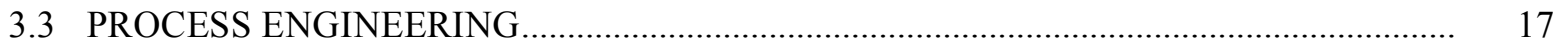

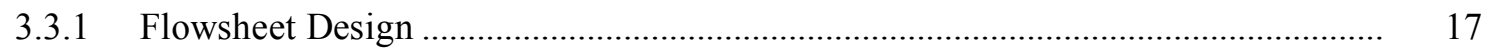

3.3.2 Contactor Size Determinations .............................................................................. 21

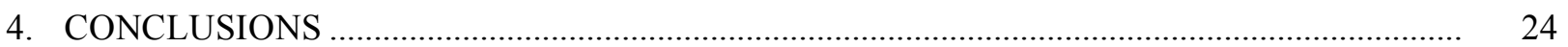

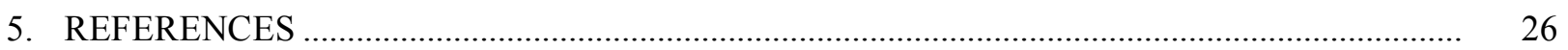


Page intentionally left blank. 


\section{LIST OF FIGURES}

Figure

Page

1 Comparison of extraction/scrub/strip batch performance of the current CSSX solvent (BOB) with the alternative solvent (BEHB) 
Page intentionally left blank. 


\section{LIST OF TABLES}

Table

Page

1 Charge-balanced candidate feeds to the Interim Pretreatment System (IPS) normalized

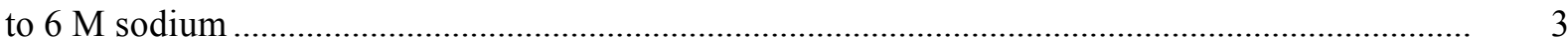

2 Stock solutions used in the makeup of the four simulants tested ................................................... 7

3 Weights of components used in the makeup of the four simulants tested ......................................... 7

4 Target vs experimental compositions of the four Hanford simulants tested ................................... 8

5 Species and formation constants used for the CSSX model in this work ...................................... 11

6 Hanford waste feed compositions used in the model................................................................... 13

7 Predicted $D_{\mathrm{Cs}}$ values using the CSSX model compared with experimental results ........................ 14

8 Batch contacting results $\left(D_{\mathrm{Cs}}\right)$ for the current CSSX solvent and four Hanford simulants .............. 15

9 Batch contacting results for two alternative CSSX solvents and four Hanford simulants ............... 16

10 Cesium distribution ratios used in flowsheet simulations ........................................................... 18

11 Flowsheet calculation results for BOBCalixC6-based solvent cases............................................ 19

12 Flowsheet calculation results for BEHBCalixC6-based solvent cases .......................................... 20

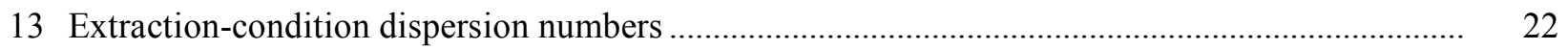

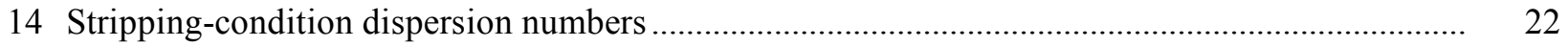

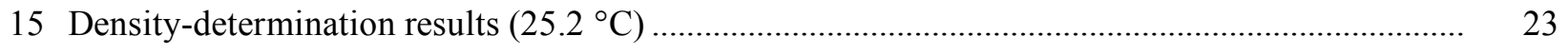

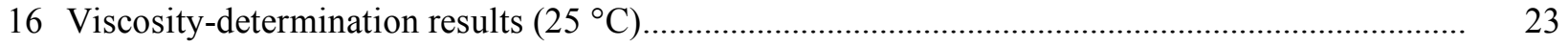


Page intentionally left blank. 


\begin{abstract}
The purpose of this work is to examine the applicability of the Caustic-Side Solvent Extraction (CSSX) process for the removal of cesium from Hanford tank-waste supernatant solutions in support of the Hanford Interim Pretreatment System (IPS). The Hanford waste types are more challenging than those at the Savannah River Site (SRS) in that they contain significantly higher levels of potassium, the chief competing ion in the extraction of cesium. It was confirmed by use of the CSSX model that the higher levels of potassium depress the cesium distribution ratio $\left(D_{\mathrm{Cs}}\right)$, as validated by measurement of $D_{\mathrm{Cs}}$ values for four of eight specified Hanford waste-simulant compositions. The model predictions were good to an apparent standard error of $\pm 11 \%$. It is concluded from batch distribution experiments, physical-property measurements, equilibrium modeling, flowsheet calculations, and contactor sizing that the CSSX process as currently employed for cesium removal from alkaline salt waste at the SRS is capable of treating similar Hanford tank feeds. For the most challenging waste composition, 41 stages would be required to provide a cesium decontamination factor (DF) of 5000 and a concentration factor (CF) of 5. Commercial contacting equipment with rotor diameters of $10 \mathrm{in}$. for extraction and $5 \mathrm{in}$. for stripping should have the capacity to meet throughput requirements, but testing will be required to confirm that the needed efficiency and hydraulic performance are actually obtainable. Markedly improved flowsheet performance was calculated for a new solvent formulation employing the more soluble cesium extractant BEHBCalixC6 used with alternative scrub and strip solutions, respectively $0.1 \mathrm{M} \mathrm{NaOH}$ and $10 \mathrm{mM}$ boric acid. The improved system can meet minimum requirements $(\mathrm{DF}=5000$ and $\mathrm{CF}=5)$ with 17 stages or more ambitious goals $(\mathrm{DF}=40,000$ and $\mathrm{CF}=15)$ with 19 stages. Potential benefits of further research and development are identified that would lead to reduced costs, greater adaptability of the process to DOE alkaline salt wastes, and greater readiness for implementation. Such benefits accrue from optimal sizing of centrifugal contactors for application of the CSSX process for the IPS; more accurate modeling of cesium extraction with greater flexibility and applicability to a variety of feeds and flowsheet conditions; and further improving and optimizing the alternative CSSX solvent and scrub/strip system.
\end{abstract}

\title{
1. INTRODUCTION
}

The purpose of this work is to examine the applicability of the Caustic-Side Solvent Extraction (CSSX) process for the removal of cesium from Hanford tank-waste supernatant solutions in support of the Hanford Interim Pretreatment System (IPS). The IPS was authorized by the U.S. Department of Energy (DOE) in December 2007 to provide pretreated low-activity waste (LAW) for early operations of the Hanford Waste Treatment Plant (WTP) LAW facility and/or operation of a supplemental immobilization technology independent of the WTP. The major function of the IPS will be cesium removal from the waste, for which the CSSX process is considered a candidate technology. The results presented herein were requested through the IPS program management to allow an evaluation of CSSX in comparison with other candidate technologies so as to select a single preferred technology for conceptual design. Feed compositions to be examined are shown in Table 1, which also shows the minimum 
decontamination factors (DFs) needed based on a maximum activity in the treated LAW of $1.5 \times 10^{-5}$ $\mathrm{Ci} / \mathrm{mol} \mathrm{Na}$. Cesium distribution ratios $\left(D_{\mathrm{Cs}}=[\mathrm{Cs}]_{\mathrm{org}} /[\mathrm{Cs}]_{\mathrm{aq}}\right)$ for extraction of the specified feed compositions by the CSSX solvent were to be either calculated using an existing thermodynamic model, provided it was found to be suitably parameterized, or determined experimentally for selected feeds. Assuming a target cesium decontamination factor (DF) of 5000 and a concentration factor (CF) in the range 5-15, the values of $D_{\mathrm{Cs}}$ corresponding to each feed are needed to calculate a flowsheet specifying the minimum number of centrifugal-contactor stages and phase flow rates needed to meet the process targets. Based on the physical properties of the phases, the contactor sizes that would furnish a throughput of $20.8 \mathrm{~L} / \mathrm{min}$. were to be determined. These results would provide the basis for follow-on plant flowsheet calculations and cost estimation for comparison of the candidate IPS technologies.

As described in a recent review [1], the CSSX process was developed for removal of cesium from highly alkaline sodium nitrate wastes of the type stored in underground tanks at the Hanford and Savannah River sites. The process as currently practiced has been optimized [2-6] and demonstrated [79] for removal of cesium from salt waste at the Savannah River Site (SRS). To meet the needs of the SRS Salt Waste Processing Facility (SWPF) [10], the CSSX process has been designed and demonstrated to remove cesium with a decontamination factor (DF) in excess of 40,000 , concentrating it by a factor (CF) of 15 in a stream of $1 \mathrm{mM} \mathrm{HNO}_{3}$ suitable for vitrification. A scaled-down implementation of CSSX is currently in operation within the Mobile CSSX Unit (MCU) at the SRS, providing a waste-treatment capability at the SRS at least four years in advance of the anticipated full-scale operation at the SWPF.

Whether a scaled-down CSSX implementation would be viable at Hanford depends primarily on the achievable cesium distribution ratios $\left(D_{\mathrm{Cs}}\right)$ using CSSX solvent for anticipated Hanford waste feeds. Early development of CSSX had in fact been targeted at Hanford type waste compositions [11,12], which can differ from the SRS wastes in having potassium concentrations as high as $1 \mathrm{M}$, compared with a maximum of $0.05 \mathrm{M}$ in SRS wastes [4,13]. Calixarene-crown extractants of the type used in the CSSX solvent are known to extract cesium vs potassium with a separation factor $\left(D_{\mathrm{Cs}} / D_{\mathrm{K}}\right)$ on the order of $10^{2}$ [14]. Despite what is evidently excellent selectivity, potassium concentrations can be on the order of $10^{2}$ times that of cesium in the waste, even at the SRS, making potassium loading of the extractant an important determinant of the achievable magnitude of $D_{\mathrm{Cs}}$. This expectation was observed experimentally with SRS simulant compositions [4,6]. The value of $D_{\mathrm{Cs}}$ obtained with the CSSX solvent for the "average" SRS waste is approximately 14 with an O:A phase ratio of 0.33 [6], allowing a DF of 40,000 to be obtained with good margin (robustness) in 15 stages. The performance of the current CSSX solvent on Hanford type feeds has not been tested. However, with earlier solvent formulations used at O:A = 1, a high-potassium Hanford type simulant gave a $D_{\mathrm{Cs}}$ value of approximately 2 [11,12], whereas two other Hanford compositions with relatively low potassium concentrations, including a complexant waste $[11,12]$ and a sludge leachate [13], gave $D_{\mathrm{Cs}}$ values of 18 and 7.9 , respectively. Thus, it may be expected that the typical Hanford feed, having much higher potassium content than the average SRS waste, will exhibit compromised extraction strength. 
Table 1. Charge-balanced candidate feeds to the Interim Pretreatment System (IPS) normalized to 6 M sodium $^{a}$

\begin{tabular}{|c|c|c|c|c|c|c|c|c|}
\hline $\begin{array}{c}\text { Waste: } \\
\text { Volume: } \\
\text { Analyte or Species }\end{array}$ & $\begin{array}{c}1 \\
241-\mathrm{AP}- \\
104 \\
3,787 \mathrm{~kL} \\
\mathrm{~mol} / \mathrm{L}\end{array}$ & $\begin{array}{c}2 \\
241-\mathrm{AP}- \\
102 \\
4,004 \mathrm{~kL} \\
\mathrm{~mol} / \mathrm{L}\end{array}$ & $\begin{array}{c}3 \\
241-\mathrm{AP}- \\
101 \\
4,126 \mathrm{~kL} \\
\mathrm{~mol} / \mathrm{L}\end{array}$ & $\begin{array}{c}4 \\
241-\mathrm{AP}- \\
103 \\
4,245 \mathrm{~kL} \\
\mathrm{~mol} / \mathrm{L}\end{array}$ & $\begin{array}{c}5 \\
241-\mathrm{AP}- \\
105 \\
3,944 \mathrm{~kL} \\
\mathrm{~mol} / \mathrm{L}\end{array}$ & $\begin{array}{c}6 \\
241-\mathrm{AP}- \\
108 \\
4,337 \mathrm{~kL} \\
\mathrm{~mol} / \mathrm{L}\end{array}$ & $\begin{array}{c}7 \\
241-\mathrm{AP}- \\
107 \\
4,318 \mathrm{~kL} \\
\mathrm{~mol} / \mathrm{L}\end{array}$ & $\begin{array}{c}8 \\
241-\mathrm{AN}- \\
104 \\
5,528 \mathrm{~kL} \\
\mathrm{~mol} / \mathrm{L}\end{array}$ \\
\hline Total $\mathrm{Cs}^{+}$ & $5.75 \mathrm{E}-05$ & $7.57 \mathrm{E}-05$ & $8.98 \mathrm{E}-05$ & $7.17 \mathrm{E}-05$ & $7.75 \mathrm{E}-05$ & $5.82 \mathrm{E}-05$ & $2.03 \mathrm{E}-04$ & $7.96 \mathrm{E}-05$ \\
\hline${ }^{99} \mathrm{Tc}\left(\mathrm{TcO}_{4}^{-}\right)$ & $6.60 \mathrm{E}-05$ & $6.77 \mathrm{E}-05$ & $6.50 \mathrm{E}-05$ & $9.30 \mathrm{E}-05$ & $9.03 \mathrm{E}-05$ & $6.19 \mathrm{E}-05$ & $9.05 \mathrm{E}-05$ & $5.69 \mathrm{E}-05$ \\
\hline $\mathrm{Al}\left(\mathrm{Al}(\mathrm{OH})_{4}{ }^{-}\right)$ & 0.42 & 0.63 & 0.30 & 0.54 & 0.46 & 0.57 & 0.31 & 0.64 \\
\hline $\mathrm{Bi}$ & $6.77 \mathrm{E}-05$ & $8.09 \mathrm{E}-05$ & $1.04 \mathrm{E}-04$ & $9.18 \mathrm{E}-05$ & $8.20 \mathrm{E}-05$ & $5.58 \mathrm{E}-05$ & $6.26 \mathrm{E}-05$ & $1.16 \mathrm{E}-05$ \\
\hline $\mathrm{Ca}$ & $1.04 \mathrm{E}-03$ & $4.85 \mathrm{E}-04$ & $7.93 \mathrm{E}-04$ & $1.24 \mathrm{E}-03$ & $1.45 \mathrm{E}-03$ & $3.83 \mathrm{E}-04$ & $4.20 \mathrm{E}-04$ & $0.00 \mathrm{E}+00$ \\
\hline $\mathrm{Cl}^{-}$ & $9.36 \mathrm{E}-02$ & $1.08 \mathrm{E}-01$ & $5.48 \mathrm{E}-02$ & $1.08 \mathrm{E}-01$ & $1.41 \mathrm{E}-01$ & $9.40 \mathrm{E}-02$ & $5.89 \mathrm{E}-02$ & $1.01 \mathrm{E}-01$ \\
\hline $\mathrm{Cr}$ & $9.20 \mathrm{E}-03$ & $8.40 \mathrm{E}-03$ & $1.21 \mathrm{E}-02$ & $9.19 \mathrm{E}-03$ & $4.76 \mathrm{E}-03$ & $1.03 \mathrm{E}-02$ & $1.54 \mathrm{E}-02$ & $3.73 \mathrm{E}-03$ \\
\hline $\mathrm{F}^{-}$ & $2.37 \mathrm{E}-02$ & $1.59 \mathrm{E}-03$ & $3.07 \mathrm{E}-02$ & $2.61 \mathrm{E}-02$ & $5.42 \mathrm{E}-03$ & $1.28 \mathrm{E}-02$ & $2.92 \mathrm{E}-02$ & $1.33 \mathrm{E}-02$ \\
\hline $\mathrm{Fe}$ & $1.08 \mathrm{E}-04$ & $6.68 \mathrm{E}-05$ & $1.09 \mathrm{E}-04$ & $2.03 \mathrm{E}-04$ & $1.81 \mathrm{E}-04$ & $1.00 \mathrm{E}-04$ & $6.10 \mathrm{E}-05$ & $1.95 \mathrm{E}-05$ \\
\hline $\mathrm{Hg}$ & $7.71 \mathrm{E}-08$ & $1.18 \mathrm{E}-11$ & $5.23 \mathrm{E}-08$ & $1.15 \mathrm{E}-07$ & $7.62 \mathrm{E}-09$ & $2.10 \mathrm{E}-09$ & $2.46 \mathrm{E}-07$ & $0.00 \mathrm{E}+00$ \\
\hline $\mathrm{K}^{+}$ & $1.17 \mathrm{E}-01$ & $8.73 \mathrm{E}-02$ & $1.47 \mathrm{E}-01$ & $9.47 \mathrm{E}-02$ & $6.80 \mathrm{E}-02$ & $1.74 \mathrm{E}-01$ & $7.49 \mathrm{E}-02$ & $5.34 \mathrm{E}-02$ \\
\hline $\mathrm{La}$ & $9.84 \mathrm{E}-06$ & $1.42 \mathrm{E}-05$ & $1.42 \mathrm{E}-05$ & $1.95 \mathrm{E}-05$ & $9.96 \mathrm{E}-06$ & $1.03 \mathrm{E}-05$ & $6.04 \mathrm{E}-06$ & $3.16 \mathrm{E}-16$ \\
\hline $\mathrm{Mn}$ & $4.70 \mathrm{E}-05$ & $3.09 \mathrm{E}-05$ & $5.91 \mathrm{E}-05$ & $3.91 \mathrm{E}-05$ & $1.80 \mathrm{E}-05$ & $2.13 \mathrm{E}-05$ & $3.14 \mathrm{E}-05$ & $5.52 \mathrm{E}-06$ \\
\hline $\mathrm{Na}^{+}$ & 6.00 & 6.00 & 6.00 & 6.00 & 6.00 & 6.00 & 6.00 & 6.00 \\
\hline $\mathrm{Ni}$ & $4.90 \mathrm{E}-04$ & $1.10 \mathrm{E}-04$ & $2.02 \mathrm{E}-04$ & $7.50 \mathrm{E}-04$ & $1.07 \mathrm{E}-03$ & $3.29 \mathrm{E}-04$ & $1.77 \mathrm{E}-04$ & $8.31 \mathrm{E}-06$ \\
\hline $\mathrm{NO}_{2}^{-}$ & 0.96 & 1.45 & 0.68 & 1.35 & 1.56 & 1.17 & 0.92 & 1.15 \\
\hline $\mathrm{NO}_{3}^{-}$ & 2.38 & 1.89 & 2.82 & 1.76 & 1.74 & 1.90 & 2.33 & 1.45 \\
\hline Oxalate $\left(\mathrm{C}_{2} \mathrm{O}_{4}{ }^{2-}\right)$ & 0.02 & 0.00 & 0.02 & 0.03 & 0.00 & 0.01 & 0.02 & 0.00 \\
\hline $\mathrm{Pb}$ & $8.86 \mathrm{E}-05$ & $2.45 \mathrm{E}-04$ & $1.03 \mathrm{E}-04$ & $1.20 \mathrm{E}-04$ & $8.77 \mathrm{E}-05$ & $9.67 \mathrm{E}-05$ & $8.28 \mathrm{E}-05$ & $3.30 \mathrm{E}-05$ \\
\hline $\mathrm{PO}_{4}^{3-}$ & $4.74 \mathrm{E}-02$ & $2.15 \mathrm{E}-02$ & $4.32 \mathrm{E}-02$ & $4.03 \mathrm{E}-02$ & $2.94 \mathrm{E}-02$ & $1.34 \mathrm{E}-02$ & $3.93 \mathrm{E}-02$ & $1.93 \mathrm{E}-02$ \\
\hline $\mathrm{Si}$ & $1.70 \mathrm{E}-03$ & $1.26 \mathrm{E}-03$ & $2.75 \mathrm{E}-03$ & $2.09 \mathrm{E}-03$ & $1.26 \mathrm{E}-03$ & $2.30 \mathrm{E}-03$ & $1.12 \mathrm{E}-03$ & $2.20 \mathrm{E}-03$ \\
\hline $\mathrm{SO}_{4}{ }^{2-}$ & $4.37 \mathrm{E}-02$ & $2.02 \mathrm{E}-02$ & $7.46 \mathrm{E}-02$ & $4.03 \mathrm{E}-02$ & $4.19 \mathrm{E}-02$ & $3.22 \mathrm{E}-02$ & $1.19 \mathrm{E}-01$ & $4.57 \mathrm{E}-02$ \\
\hline $\mathrm{Sr}$ & $8.64 \mathrm{E}-06$ & $9.92 \mathrm{E}-06$ & $1.13 \mathrm{E}-05$ & $1.36 \mathrm{E}-05$ & $4.74 \mathrm{E}-06$ & $4.54 \mathrm{E}-06$ & $2.22 \mathrm{E}-06$ & $0.00 \mathrm{E}+00$ \\
\hline $\mathrm{TIC}$ as $\mathrm{CO}_{3}{ }^{2-}$ & $3.60 \mathrm{E}-01$ & $2.02 \mathrm{E}-01$ & $4.05 \mathrm{E}-01$ & $4.36 \mathrm{E}-01$ & $2.88 \mathrm{E}-01$ & $3.67 \mathrm{E}-01$ & $4.81 \mathrm{E}-01$ & $3.73 \mathrm{E}-01$ \\
\hline $\mathrm{TOC}^{\mathrm{b}}$ & $2.36 \mathrm{E}-01$ & $1.38 \mathrm{E}-01$ & $1.38 \mathrm{E}-01$ & $4.10 \mathrm{E}-01$ & $2.89 \mathrm{E}-01$ & $1.95 \mathrm{E}-01$ & $1.54 \mathrm{E}-01$ & $7.60 \mathrm{E}-02$ \\
\hline $\begin{array}{l}\text { U TOTAL (as } \\
\left.\left(\mathrm{UO}_{2}\right)\left(\mathrm{CO}_{3}\right)^{4{ }^{4}}\right)\end{array}$ & & & & & & & 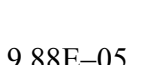 & \\
\hline $\mathrm{Zr}$ & $1.51 \mathrm{E}-05$ & $1.71 \mathrm{E}-05$ & $\begin{array}{l}0.40 \mathrm{E}-0 \mathrm{~J} \\
2.16 \mathrm{E}-05\end{array}$ & $2.27 \mathrm{E}-05$ & $\begin{array}{l}1.42 \mathrm{E}-0 \mathrm{~J} \\
1.05 \mathrm{E}-05\end{array}$ & $2.37 \mathrm{E}-05$ & $2.13 \mathrm{E}-05$ & $1.13 \mathrm{E}-05$ \\
\hline Free $\mathrm{OH}^{-}$ & 1.12 & 1.41 & 1.04 & 0.96 & 1.26 & 1.45 & 0.96 & 1.74 \\
\hline${ }^{137} \mathrm{Cs}$ in $\mathrm{Ci} / \mathrm{L}$ & 0.14 & 0.18 & 0.21 & 0.17 & 0.18 & 0.14 & 0.48 & 0.19 \\
\hline Required $\mathrm{DF}^{c}$ & 1600 & 2000 & 2400 & 1900 & 2000 & 1600 & 5400 & 2200 \\
\hline
\end{tabular}

${ }^{a}$ Concentrations in moles per liter unless otherwise indicated. Scientific notation as, for example, “3.51E-05" means " $3 \times 10^{-5}$ ". Analytes are given as presumed species where possible. ${ }^{b}$ The totalorganic-carbon (TOC) molarity values are moles of carbon per liter; for charge-balancing purposes, the TOC molarity values must be divided by 6 , then multiplied by $-3 .{ }^{c}$ The required decontamination factors (DFs) are calculated based on a maximum activity in the treated LAW of $1.5 \times 10^{-5} \mathrm{Ci} / \mathrm{mol}$ $\mathrm{Na}$; they are rounded upward to the nearest hundred.

Accordingly, one of the objectives of this report is, in effect, to quantify the effect of potassium insofar as the ability of the CSSX process to meet IPS target process performance in a reasonably small number of stages. It may be noted that stripping, performed in the flowsheet by contacting the loaded solvent with $1 \mathrm{mM} \mathrm{HNO}_{3}$ at $\mathrm{O}: \mathrm{A}=5$, should not be affected, because two scrub stages with $50 \mathrm{mM}$ $\mathrm{HNO}_{3}$ at $\mathrm{O}: \mathrm{A}=5$ wash out sodium and potassium salts from the solvent. With stripping fixed at $\mathrm{O}: \mathrm{A}=5$, for example, the maximum $\mathrm{O}$ : A ratio in the extraction section can be at most $1.0,0.5$, and 0.33 to achieve 
CFs of 5,10, and 15, respectively. An extraction O:A ratio of 1 then implies that the lowest value of $D_{\mathrm{Cs}}$ that can be tolerated to avoid pinching is 1 . Because extraction distribution ratios should be at least twice this absolute minimum for robustness, the needed $D_{\mathrm{Cs}}$ values for viability for IPS purposes would appear to be no less than 2. Higher CF values would require higher values of $D_{\mathrm{Cs}}$; thus, $\mathrm{CF}$ values of 10 and 15 would respectively require needed $D_{\mathrm{Cs}}$ values of no less than 4 and 6 .

It was concluded at the outset of this work that a combination of experiment and equilibrium modeling would be desirable for determination of the values of $D_{\mathrm{Cs}}$ needed for CSSX flowsheet calculations on each of the feeds given in Table 1. Given that the process is expected to run in the temperature range $15-25^{\circ} \mathrm{C}$, the exothermic nature of the extraction process $[4,6]$ implies that $D_{\mathrm{Cs}}$ values will be lowest at $25{ }^{\circ} \mathrm{C}$ and need only be found for this temperature to ensure adequate performance over the entire temperature range. An equilibrium model was earlier developed for the prediction of $D_{\mathrm{Cs}}$ values for the CSSX solvent as a function of aqueous-phase composition at $25{ }^{\circ} \mathrm{C}$ [16,17]. The model was validated by comparison of predicted vs experimental $D_{\mathrm{Cs}}$ values for SRS type wastes [18], where the standard error of the predictions was $\pm 4 \%$ for simulant compositions. The standard error rose to $\pm 10 \%$ for actual wastes, the increase being attributed to the lower accuracy of the stated composition of the actual wastes. An inverse correlation between $D_{\mathrm{Cs}}$ and potassium concentration was noted for the SRS waste simulants, which contained up to $59 \mathrm{mM}$ (later found to be higher than the actual waste value of $40 \mathrm{mM}$ ). Reasonable agreement was obtained in predicted vs observed $D_{\mathrm{Cs}}$ values on adding up to $100 \mathrm{mM}$ potassium to two of the SRS waste simulants. Total sodium in the SRS waste feeds was in the range 5.66.2 M, considered comparable to the Hanford compositions listed in Table 1. However, the Hanford compositions contain 53-174 mM potassium, significantly higher than the SRS wastes. It was therefore judged desirable to validate the model against four Hanford waste compositions up to the highest potassium concentration, expected to produce values of $D_{\mathrm{Cs}}$ that are much lower than the range over which the model was validated and that approach the lower limits needed to attain the target CF values of $5-15$.

The primary emphasis in the modeling, experimental testing, and flowsheet calculations was focused on the current CSSX solvent composition, but it was also of interest herein to show that an improved solvent formulation and stripping method could potentially yield markedly better flowsheet performance. The current CSSX solvent consists of $0.007 \mathrm{M}$ calix[4]arene-bis(tert-octylbenzo-crown-6), known as BOBCalixC6; 0.75 M 1-(2,2,3,3-tetrafluoropropoxy)-3-(4-sec-butylphenoxy)-2-propanol, known as Cs7SB modifier; and $0.003 \mathrm{M}$ tri- $n$-octylamine (TOA) in the diluent Isopar ${ }^{\mathbb{B}} \mathrm{L}$. The development of this solvent system and the function of each of the solvent components have been described in a recent review [1]. Although the solvent has been optimized for SRS wastes [5,6], it is herein considered adequate for trial purposes as a candidate technology for the Hanford IPS, with the above-described expectation of lower $D_{\mathrm{Cs}}$ values and somewhat less effective performance relative to SRS waste processing. Obviously, performance could be improved if the extraction $D_{\mathrm{Cs}}$ value could be increased while not simultaneously increasing the stripping $D_{\mathrm{Cs}}$ value. This is not possible by changing the concentrations of the components in the current CSSX solvent. The concentration of BOBCalixC6 is already at just below its solubility limit in the modified solvent [6], and increases in Cs-7SB concentration decrease hydraulic performance, effectively resulting in lower throughput [5]. Even if such limitations did not exist, increasing either or 
both the extractant or modifier concentrations would tend to raise the stripping $D_{\mathrm{Cs}}$ value by approximately the same factor as it would raise the extraction $D_{\mathrm{Cs}}$ value, yielding no overall benefit. Recently, approaches to resolving this dilemma have been proposed [19]. Most promising for near-term application is to simultaneously raise the extraction $D_{\mathrm{Cs}}$ value by increasing the extractant concentration and lower the stripping $D_{\mathrm{Cs}}$ value by changing the scrub and strip solutions [20]. It is possible to increase the extractant concentration by replacing $\mathrm{BOBCalixC6}$ with its analog in which the tert-octyl groups are replaced with 2-ethylhexyl groups. An isomer of BOBCalixC6, the resulting compound, calix[4]arenebis(2-ethylhexylbenzocrown-6) (BEHBCalixC6), has been shown to have nearly identical extraction properties compared with BOBCalixC6 [21], which is understandable in that the substitution is remote from the $\mathrm{Cs}^{+}$ion binding site. However, the 2-ethylhexyl groups confer much greater solubility, which is apparently in excess of $50 \mathrm{mM}$ in the CSSX process solvent. Given a roughly first-power dependence of $D_{\mathrm{Cs}}$ on calixarene concentration, it is therefore anticipated that a three-fold increase in calixarene concentration could restore extraction $D_{\mathrm{Cs}}$ values for Hanford waste feeds to values comparable to those obtained for SRS feeds. Stripping has been dramatically improved by scrubbing the loaded CSSX solvent with $0.1 \mathrm{M} \mathrm{NaOH}$ at $\mathrm{O}: \mathrm{A}=5$ and then stripping with $10 \mathrm{mM}$ boric acid. This stripping enhancement can be obtained with the current CSSX solvent using BOBCalixC6. Alternatively, the substitution of BEHBCalixC6 at a higher concentration would be expected to produce simultaneous improvement in both extraction and stripping. An additional possibility is to replace the TOA with a guanidine type extractant [20], which was shown to produce another order of magnitude in improvement in stripping. In the present work, the current CSSX solvent system is tested at $25^{\circ} \mathrm{C}$ using the standard scrubbing with 50 $\mathrm{mM} \mathrm{HNO}$ at $\mathrm{O}: \mathrm{A}=5$ and stripping with $1 \mathrm{mM} \mathrm{HNO}_{3}$ at $\mathrm{O}: \mathrm{A}=5$. These results are compared with parallel tests with two alternative solvent formulations, one with TOA and one with the guanidine, with the alternative scrubbing and stripping using respectively $0.1 \mathrm{M} \mathrm{NaOH}$ and $10 \mathrm{mM}$ boric acid. 


\section{EXPERIMENTAL SECTION}

\subsection{CHEMICALS, WASTE SIMULANTS, AND SOLVENTS}

Waste simulants and stock solutions of single salts were prepared directly from ACS (American Chemical Society) grade reagents. For those that were needed in very small quantities in the simulants, it was decided to prepare stock solutions so that these salts could be added volumetrically, as shown in Table 2. The other compounds needed for the simulants were weighed as shown in Table 3 . The target vs experimental solution concentrations expected according to exact amounts weighed out are given in Table 4. In most cases, the as-weighed expected concentrations were within 1-2\% of the targets. An exception was $\mathrm{CsNO}_{3}$, which was $11 \%$ higher than the target; this is considered a negligible difference, in that to the extent that its effect is noticeable is actually a slightly more severe condition for the experimental tests, giving a slightly higher loading effect than otherwise expected; loading effects were found to be of negligible consequence (see below). Deionized water was used to prepare all aqueous solutions. Some precipitate was noted in the prepared waste simulants. It is assumed that the precipitates consist of insoluble hydroxides, phosphates, or carbonates of di-, tri-, and tetravalent metals [e.g., Fe(III), La(III), $\mathrm{Ni}(\mathrm{II}), \mathrm{Pb}(\mathrm{II}), \mathrm{Zr}(\mathrm{IV})$, etc.], and thus, the by-weight concentration expected for these metals given in Table 4 may not correspond to actual concentrations. The radiotracer ${ }^{137} \mathrm{Cs}$ was obtained from Isotope Products, Burbank, CA. It was not added to the simulant stocks but rather was added as spikes to the sample equilibration vials in the extraction experiments.

The current CSSX solvent consisted of 0.007 M BOBCalixC6 (IBC lot\# 011116KCORNL005), 0.750 M Cs-7SB modifier (Marshallton lot\# MOD0701-a), 0.003 M tri- $n$-octylamine (TOA) (Aldrich, lot No. B00894-188T), and Isopar ${ }^{\circledR}$ L (Exxon, lot No. 03081001-6-2). A conditioning procedure was employed in which the solvent was contacted at $\mathrm{O}: \mathrm{A}=1$ twice with $0.1 \mathrm{M} \mathrm{NaOH}$, twice with $0.05 \mathrm{M} \mathrm{HNO}_{3}$, and three times with deionized water. The solvent passed the quality check performed by the procedure specified earlier [22], involving contacting the solvent at $\mathrm{O}: \mathrm{A}=1$ and $25^{\circ} \mathrm{C}$ with a simple simulant $(2 \mathrm{M} \mathrm{NaOH}, 3$ $\mathrm{M} \mathrm{NaNO}_{3}$, and $0.50 \mathrm{mM} \mathrm{CsNO}_{3}$ ), $50 \mathrm{mM} \mathrm{HNO}_{3}$, and $1 \mathrm{mM} \mathrm{HNO}_{3}$. The $D_{\mathrm{Cs}}$ values obtained were 15.7, 1.42 , and 0.0238 , within the specified ranges $16.3 \pm 1.1,1.46 \pm 0.12$, and $0.0280 \pm 0.0047$.

Two alternative CSSX solvents were tested. The first consisted of $0.020 \mathrm{M}$ BEHBCalixC6 (ChemoDynamics), $0.750 \mathrm{M}$ Cs-7SB modifier, and $0.003 \mathrm{M}$ TOA in Isopar ${ }^{\mathbb{B}}$ L. The second alternative CSSX solvent had the same composition except that the TOA was replaced by the guanidine extractant that is the active ingredient of LIX $^{\circledR} 79$ (Cognis), a commercial extraction solvent used for the hydrometallurgical recovery of gold and silver from cyanide leaching of ore. As described elsewhere [20], the guanidine compound was precipitated as the chloride form using $10 \mathrm{M} \mathrm{HCl}$ from a LIX 79 sample supplied by Cognis. 
Table 2. Stock solutions used in the makeup of the four simulants tested ${ }^{a}$

\begin{tabular}{cc|c|c|c|c}
\hline Salt & $\begin{array}{c}\text { Conc. } \\
\mathrm{mol} / \mathrm{L}\end{array}$ & $\begin{array}{c}\text { Simulant \#3 } \\
\mathrm{mL}\end{array}$ & $\begin{array}{c}\text { Simulant \#6 } \\
\mathrm{mL}\end{array}$ & $\begin{array}{c}\text { Simulant \#7 } \\
\mathrm{mL}\end{array}$ & $\begin{array}{c}\text { Simulant \#8 } \\
\mathrm{mL}\end{array}$ \\
\hline $\mathrm{CsNO}_{3}$ & 0.1 & 0.449 & 0.291 & 1.015 & 0.398 \\
$\mathrm{Ca}\left(\mathrm{NO}_{3}\right)_{2} \cdot 4 \mathrm{H}_{2} \mathrm{O}$ & 0.1 & 3.965 & 1.915 & 2.100 & - \\
$\mathrm{Fe}\left(\mathrm{NO}_{3}\right)_{3} .9 \mathrm{H}_{2} \mathrm{O}$ & 0.1 & 0.545 & 0.500 & 0.305 & 0.098 \\
$\mathrm{HgCl}_{2}$ & 0.01 & 0.003 & 0.000 & 0.012 & - \\
$\mathrm{La}\left(\mathrm{NO}_{3}\right)_{3}$ & 0.01 & 0.710 & 0.515 & 0.302 & - \\
$\mathrm{KMnO}_{4}$ & 0.01 & 2.955 & 1.065 & 1.570 & 0.276 \\
$\mathrm{NiCl}_{2} \cdot 6 \mathrm{H}_{2} \mathrm{O}$ & 0.05 & 2.020 & 3.290 & 1.770 & 0.083 \\
$\mathrm{~Pb}_{\left(\mathrm{NO}_{3}\right)_{2}}$ & 0.05 & 1.030 & 0.967 & 0.828 & 0.330 \\
$\mathrm{Sr}_{\left(\mathrm{NO}_{3}\right)_{2}}$ & 0.01 & 0.565 & 0.227 & 0.111 & - \\
$\mathrm{ZrOCl}$ & \\
\hline
\end{tabular}

${ }^{\mathrm{a}}$ Each simulant was made up to a total volume of $500 \mathrm{~mL}$.

Table 3. Weights of components used in the makeup of the four simulants tested ${ }^{a}$

\begin{tabular}{cc|c|c|c|c}
\hline Salt & FW & Simulant \#3 & Simulant \#6 & Simulant \#7 & Simulant \#8 \\
& $\mathrm{g} / \mathrm{mol}$ & $\mathrm{g}$ & $\mathrm{g}$ & $\mathrm{g}$ & $\mathrm{g}$ \\
\hline $\mathrm{Na}_{2} \mathrm{O} . \mathrm{Al}_{2} \mathrm{O}_{3} .3 \mathrm{H}_{2} \mathrm{O}$ & 218 & 16.350 & 31.065 & 16.895 & 34.880 \\
$\mathrm{Bi}\left(\mathrm{NO}_{3}\right)_{3} .5 \mathrm{H}_{2} \mathrm{O}$ & 484.9 & 0.025 & 0.014 & 0.015 & 0.003 \\
$\mathrm{Na}_{2} \mathrm{CrO}_{4}$ & 161.97 & 0.980 & 0.834 & 1.247 & 0.302 \\
$\mathrm{NaF}$ & 42 & 0.645 & 0.269 & 0.613 & 0.279 \\
$\mathrm{NaNO}_{2}$ & 69 & 23.460 & 40.365 & 31.740 & 39.675 \\
$\mathrm{Na}_{2} \mathrm{C}_{2} \mathrm{O}_{4}$ & 134 & 1.340 & 0.670 & 1.340 & - \\
$\mathrm{Na}_{2} \mathrm{HPO}_{4}$ & 141.96 & 3.066 & 0.951 & 2.790 & 1.370 \\
$\mathrm{Na}_{2} \mathrm{SiO}_{3}$ & 212.15 & 0.292 & 0.244 & 0.119 & 0.233 \\
$\mathrm{Na}_{2} \mathrm{SO}_{4}$ & 142 & 5.297 & 2.286 & 8.449 & 3.245 \\
$\mathrm{Na}_{2} \mathrm{CO}_{3}$ & 106 & 21.465 & 19.451 & 25.493 & 19.769 \\
$\mathrm{Na}_{3} \mathrm{C}_{6} \mathrm{H}_{5} \mathrm{O}_{7}$ & 294.1 & 3.382 & 4.779 & 3.774 & 1.863 \\
$\mathrm{NaNO}_{3}$ & 85 & 113.495 & 73.291 & 95.775 & 59.346 \\
$\mathrm{NaCl}$ & 58.5 & 1.590 & 2.729 & 1.711 & 2.953 \\
$\mathrm{KNO}_{3}$ & 101 & 7.421 & 8.786 & 3.781 & 2.696 \\
$\mathrm{NaOH}$ & 40 & 21.664 & 29.268 & 19.986 & 35.186 \\
\hline
\end{tabular}

${ }^{\mathrm{a}}$ Each simulant was made up to $500 \mathrm{~mL}$. 
Table 4. Target vs experimental compositions of the four Hanford simulants tested ${ }^{a}$

\begin{tabular}{|c|c|c|c|c|c|c|c|c|}
\hline \multirow[t]{2}{*}{ Salt } & \multicolumn{2}{|c|}{ Simulant \#3 } & \multicolumn{2}{|c|}{ Simulant \#6 } & \multicolumn{2}{|c|}{ Simulant \#7 } & \multicolumn{2}{|c|}{ Simulant \#8 } \\
\hline & $\begin{array}{l}\text { Target } \\
\mathrm{mol} / \mathrm{L}\end{array}$ & $\begin{array}{l}\text { Exper. } \\
\text { mol/L }\end{array}$ & $\begin{array}{l}\text { Target } \\
\mathrm{mol} / \mathrm{L}\end{array}$ & $\begin{array}{l}\text { Exper. } \\
\text { mol/L }\end{array}$ & $\begin{array}{l}\text { Target } \\
\mathrm{mol} / \mathrm{L}\end{array}$ & $\begin{array}{l}\text { Exper. } \\
\text { mol/L }\end{array}$ & $\begin{array}{l}\text { Target } \\
\mathrm{mol} / \mathrm{L}\end{array}$ & $\begin{array}{l}\text { Exper. } \\
\text { mol/L }\end{array}$ \\
\hline $\mathrm{CsNO}_{3}$ & $8.98 \mathrm{E}-05$ & $1.00 \mathrm{E}-04$ & $5.82 \mathrm{E}-05$ & $6.51 \mathrm{E}-05$ & $2.03 \mathrm{E}-04$ & $2.27 \mathrm{E}-04$ & $7.96 \mathrm{E}-05$ & 8.91E-05 \\
\hline $\mathrm{Na}_{2} \mathrm{O} \cdot \mathrm{Al}_{2} \mathrm{O}_{3} \cdot 3 \mathrm{H}_{2} \mathrm{O}$ & 0.150 & 0.150 & 0.285 & 0.285 & 0.155 & 0.155 & 0.320 & 0.320 \\
\hline $\mathrm{Bi}\left(\mathrm{NO}_{3}\right)_{3} .5 \mathrm{H}_{2} \mathrm{O}$ & $1.04 \mathrm{E}-04$ & $1.03 \mathrm{E}-04$ & $5.58 \mathrm{E}-05$ & $5.77 \mathrm{E}-05$ & $6.26 \mathrm{E}-05$ & $6.19 \mathrm{E}-05$ & $1.16 \mathrm{E}-05$ & $1.24 \mathrm{E}-05$ \\
\hline $\mathrm{Ca}\left(\mathrm{NO}_{3}\right)_{2} \cdot 4 \mathrm{H}_{2} \mathrm{O}$ & $7.93 \mathrm{E}-04$ & $7.86 \mathrm{E}-04$ & $3.83 \mathrm{E}-04$ & $3.80 \mathrm{E}-04$ & $4.20 \mathrm{E}-04$ & 4.17E-04 & 0 & 0 \\
\hline $\mathrm{Na}_{2} \mathrm{CrO}_{4}$ & $1.21 \mathrm{E}-02$ & $1.22 \mathrm{E}-02$ & $1.03 \mathrm{E}-02$ & $1.03 \mathrm{E}-02$ & $1.54 \mathrm{E}-02$ & $1.54 \mathrm{E}-02$ & $3.73 \mathrm{E}-03$ & $3.73 \mathrm{E}-03$ \\
\hline $\mathrm{NaF}$ & $3.07 \mathrm{E}-02$ & $3.08 \mathrm{E}-02$ & $1.28 \mathrm{E}-02$ & $1.28 \mathrm{E}-02$ & $2.92 \mathrm{E}-02$ & $2.92 \mathrm{E}-02$ & $1.33 \mathrm{E}-02$ & $1.33 \mathrm{E}-02$ \\
\hline $\mathrm{Fe}\left(\mathrm{NO}_{3}\right)_{3} .9 \mathrm{H}_{2} \mathrm{O}$ & $1.09 \mathrm{E}-04$ & $1.16 \mathrm{E}-04$ & $1.00 \mathrm{E}-04$ & $1.07 \mathrm{E}-04$ & $6.10 \mathrm{E}-05$ & $6.51 \mathrm{E}-05$ & $1.95 \mathrm{E}-05$ & $2.09 \mathrm{E}-05$ \\
\hline $\mathrm{HgCl}_{2}$ & $5.23 \mathrm{E}-08$ & $6.00 \mathrm{E}-08$ & $2.10 \mathrm{E}-09$ & 0 & $2.46 \mathrm{E}-07$ & $2.40 \mathrm{E}-07$ & 0 & 0 \\
\hline $\mathrm{La}\left(\mathrm{NO}_{3}\right)_{3}$ & $1.42 \mathrm{E}-05$ & $1.42 \mathrm{E}-05$ & $1.03 \mathrm{E}-05$ & $1.03 \mathrm{E}-05$ & $6.04 \mathrm{E}-06$ & $6.04 \mathrm{E}-06$ & 0 & 0 \\
\hline $\mathrm{KMnO}_{4}$ & $5.91 \mathrm{E}-05$ & $5.91 \mathrm{E}-05$ & $2.13 \mathrm{E}-05$ & $2.13 \mathrm{E}-05$ & $3.14 \mathrm{E}-05$ & $3.14 \mathrm{E}-05$ & $5.52 \mathrm{E}-06$ & $5.52 \mathrm{E}-06$ \\
\hline $\mathrm{NiCl}_{2} \cdot 6 \mathrm{H}_{2} \mathrm{O}$ & $2.02 \mathrm{E}-04$ & $2.02 \mathrm{E}-04$ & $3.29 \mathrm{E}-04$ & $3.29 \mathrm{E}-04$ & $1.77 \mathrm{E}-04$ & $1.77 \mathrm{E}-04$ & $8.31 \mathrm{E}-06$ & $8.30 \mathrm{E}-06$ \\
\hline $\mathrm{NaNO}_{2}$ & 0.68 & 0.67 & 1.17 & 1.17 & 0.920 & 0.919 & 1.15 & 1.15 \\
\hline $\mathrm{Na}_{2} \mathrm{C}_{2} \mathrm{O}_{4}$ & 0.02 & $2.01 \mathrm{E}-02$ & 0.01 & $9.94 \mathrm{E}-03$ & 0.0200 & $2.00 \mathrm{E}-02$ & 0 & 0 \\
\hline $\mathrm{Pb}\left(\mathrm{NO}_{3}\right)_{2}$ & $1.03 \mathrm{E}-04$ & $1.03 \mathrm{E}-04$ & $9.67 \mathrm{E}-05$ & $9.67 \mathrm{E}-05$ & $8.28 \mathrm{E}-05$ & $8.28 \mathrm{E}-05$ & $3.30 \mathrm{E}-05$ & $3.30 \mathrm{E}-05$ \\
\hline $\mathrm{Na}_{2} \mathrm{HPO}_{4}$ & 4.32E-02 & $4.31 \mathrm{E}-02$ & $1.34 \mathrm{E}-02$ & $1.34 \mathrm{E}-02$ & $3.92 \mathrm{E}-02$ & $3.93 \mathrm{E}-02$ & $1.93 \mathrm{E}-02$ & $1.94 \mathrm{E}-02$ \\
\hline $\mathrm{Na}_{2} \mathrm{SiO}_{3}$ & $2.75 \mathrm{E}-03$ & $2.76 \mathrm{E}-03$ & $2.30 \mathrm{E}-03$ & $2.30 \mathrm{E}-03$ & $1.12 \mathrm{E}-03$ & $1.12 \mathrm{E}-03$ & $2.20 \mathrm{E}-03$ & $2.20 \mathrm{E}-03$ \\
\hline $\mathrm{Na}_{2} \mathrm{SO}_{4}$ & $7.46 \mathrm{E}-02$ & $7.45 \mathrm{E}-02$ & $3.22 \mathrm{E}-02$ & $3.23 \mathrm{E}-02$ & 0.119 & 0.119 & $4.57 \mathrm{E}-02$ & $4.58 \mathrm{E}-02$ \\
\hline $\mathrm{Sr}\left(\mathrm{NO}_{3}\right)_{2}$ & $1.13 \mathrm{E}-05$ & $1.13 \mathrm{E}-05$ & $4.54 \mathrm{E}-06$ & $4.55 \mathrm{E}-06$ & $2.22 \mathrm{E}-06$ & $2.22 \mathrm{E}-06$ & 0 & 0 \\
\hline $\mathrm{Na}_{2} \mathrm{CO}_{3}$ & $4.05 \mathrm{E}-01$ & $4.05 \mathrm{E}-01$ & $3.67 \mathrm{E}-01$ & $3.67 \mathrm{E}-01$ & 0.481 & $4.81 \mathrm{E}-01$ & 0.373 & $3.73 \mathrm{E}-01$ \\
\hline $\mathrm{Na}_{3} \mathrm{C}_{6} \mathrm{H}_{5} \mathrm{O}_{7}$ & $2.30 \mathrm{E}-02$ & $2.30 \mathrm{E}-02$ & $3.25 \mathrm{E}-02$ & $3.24 \mathrm{E}-02$ & $2.57 \mathrm{E}-02$ & $2.56 \mathrm{E}-02$ & $1.27 \mathrm{E}-02$ & $1.27 \mathrm{E}-02$ \\
\hline $\mathrm{ZrOCl}_{2} \cdot 8 \mathrm{H}_{2} \mathrm{O}$ & $2.16 \mathrm{E}-05$ & $2.12 \mathrm{E}-02$ & $2.37 \mathrm{E}-05$ & $2.32 \mathrm{E}-05$ & $2.13 \mathrm{E}-05$ & $2.09 \mathrm{E}-05$ & $1.13 \mathrm{E}-05$ & $1.11 \mathrm{E}-05$ \\
\hline $\mathrm{NaNO}_{3}$ & 2.67 & 2.67 & 1.72 & 1.72 & 2.25 & 2.25 & 1.40 & 1.40 \\
\hline $\mathrm{NaCl}$ & $5.44 \mathrm{E}-02$ & $5.43 \mathrm{E}-02$ & $9.33 \mathrm{E}-02$ & $9.34 \mathrm{E}-02$ & $5.85 \mathrm{E}-02$ & $5.85 \mathrm{E}-02$ & 0.101 & 0.101 \\
\hline $\mathrm{KNO}_{3}$ & $1.47 \mathrm{E}-01$ & $1.47 \mathrm{E}-01$ & 0.174 & 0.174 & 7.49E-02 & 7.49E-02 & $5.34 \mathrm{E}-02$ & $5.33 \mathrm{E}-02$ \\
\hline $\mathrm{NaOH}$ & 1.04 & 1.08 & 1.45 & 1.46 & 0.960 & 0.996 & 1.74 & 1.76 \\
\hline
\end{tabular}

a"Exper." values correspond to the expected concentrations assuming that the entire weighed amount of each compound remains in solution. Precipitates formed in each simulant, indicating that the actual concentration achieved for the metals of higher valency may not correspond to the "Exper." expectation.

\subsection{GENERAL SOLVENT-EXTRACTION AND COUNTING PROCEDURE}

Capped $2 \mathrm{~mL}$ polypropylene micro-tubes were mounted by clips on a disk that was rotated in a constant-temperature air box at $25.0 \pm 0.5^{\circ} \mathrm{C}$ for 30 minutes. After the contacting period, the tubes were centrifuged for 3 minutes at $3000 \mathrm{RPM}$ and $25{ }^{\circ} \mathrm{C}$ in a Beckman Coulter ${ }^{\mathrm{TM}}$ Allegra 6R temperaturecontrolled centrifuge. A $300 \mu \mathrm{L}$ aliquot of each phase was subsampled and counted using a Packard 
Cobra II Auto-Gamma counter. Aqueous phases were counted for a period of 5 minutes; organic phases were counted for 10 minutes using a window of 580-750 keV. Counting times were sufficient to ensure that counting error was a negligible fraction of overall precision, considered to be $\pm 5 \%$. In the usual manner [2-6], cesium distribution ratios $\left(D_{\mathrm{Cs}}\right)$ were determined as the ratio of the background-corrected volumetric count rates of the radioisotope in each phase at equilibrium.

\subsection{PHYSICAL-PROPERTY DETERMINATIONS}

Verification of acceptable phase-separation performance and selection of contactor size(s) required to obtain the processing rate desired for the subject application necessitated determination of physical properties affecting or describing separation of dispersions comprising typical Hanford wastes and CSSX solvent. Due to project time constraints and the limited availability of the BEHBCalixC6-based solvent, characterizations of phase-separation behavior and property determinations were limited to BOBCalixC6based solvent, simulants that were "bracketing" with respect to concentrations of cesium, potassium, nitrate ion, hydroxide ion, and total ionic strength, and dispersions of BOBCalixC6 with these simulants. The subset of test dispersions was further limited to BOBCalixC6/scrub solution and BOBCalixC6/strip solution pairs derived from extractions from Simulants \#6 and \#8 after these solvent/simulant extraction pairs were found to be worst case with respect to phase separation.

Three properties were determined: viscosity of simulants and the BOBCalixC6 solvent, density of these components, and the dimensionless dispersion number that quantifies phase separation performance. The latter quantity is defined by the expression [23]

$$
N_{D i}=\frac{1}{t_{b}} \sqrt{\frac{z}{a}}
$$

in which $N_{D i}$ is the dispersion number, $z$ is the initial height of a dispersed column of solvent and aqueous solutions, $a$ is the acceleration applied to separate the dispersion, and $t_{b}$ is the time required for the dispersion band to collapse into its component phases. In the case of gravity settling, $a$ is replaced by the gravitational constant.

Dispersion numbers were determined for dispersions of the BOBCalixC6-based solvent with each of the four bracketing simulants at the 1:3 O:A phase ratio used in the extraction section of the SRS CSSX flow sheet. In each case, $60 \mathrm{~mL}$ of simulant was placed into a graduated cylinder to which $20 \mathrm{~mL}$ of solvent was then added. The position of the interface was recorded as was the height of the liquid column. The cylinder was stoppered, agitated manually for $20 \mathrm{~s}$, allowed to settle for $10 \mathrm{~s}$, and agitated for a second time for $20 \mathrm{~s}$. The time required for the interface to return to its original level was measured beginning at the end of the second period of agitation. All determinations were repeated a minimum of four times (giving a minimum of five measurements) for each simulant/solvent pair. All replicates were performed using the original aliquots of simulant and solvent. 
Dispersion-number determinations were made under scrubbing and stripping conditions (O:A ratios of 5:1) using extracts generated by $N_{D i}$ determinations involving Simulants $\# 6$ and $\# 8$. The procedure was identical to that used for extraction-condition $N_{D i}$ measurements.

Density determinations were made gravimetrically; $10 \mathrm{~mL}$ volumes of solutions were placed into tared flasks using a calibrated manual pipettor. Total masses of solution and flask were determined using a Mettler model AE260 Delta Range ${ }^{\circledR}$ balance, which has a resolution to the fourth decimal place (ten thousandths). Determinations were made at ambient laboratory temperature, which was $25.2{ }^{\circ} \mathrm{C}$.

Viscosity determinations were made for the BOBCalixC6-based solvent, Simulants \#6 and \#8, and scrub and strip solutions recovered from scrub and strip dispersion-number determinations pertaining to these simulants. Viscosity measurements were made using a Brookfield digital-indicating, model LV viscometer, equipped with a model ULA-40Y water jacket, a model ULA-31Y sample container, and a model YULA-15 spindle. The water jacket was connected to a water bath that was maintained at $25.0{ }^{\circ} \mathrm{C}$ using a Cole-Parmer Polystat circulating heater (model 1253-00). Prior to use, the viscometer calibration was checked using deionized water and a standard viscosity solution (Brookfield Fluid 50, Lot no. 050604 , with a viscosity of $48.6 \mathrm{cP}$ at $25.0{ }^{\circ} \mathrm{C}$ ). The calibration check indicated that the apparatus was accurate to within $\pm 0.2 \%$. 


\section{RESULTS AND DISCUSSION}

\subsection{PREDICTION OF CESIUM DISTRIBUTION RATIOS USING CSSX MODEL}

The model established in 2003 [16] was used here to predict the $D_{\mathrm{Cs}}$ values based on the Hanford feed compositions given in Table 1. The model is based on general extraction equilibria for univalent metal salts MX, given as

$$
n \mathrm{M}^{+}+n \mathrm{X}^{-}+\text {Calix (org) } \rightleftharpoons(\mathrm{MX})_{n} \text { Calix (org) }
$$

Formal species employed in the model are given in Table 5. The ability of bis-crown-6 calix[4]arenes like BOBCalixC6 to accommodate two metal ions, owing to the presence of two identical cation-binding cavities in each molecule, is reflected in the species $\left(\mathrm{CsNO}_{3}\right)_{2}$ Calix [24]. This species makes the model applicable to high-loading conditions, which are possible but not generally seen with the CSSX process. All other species have a single metal ion, including $\mathrm{Na}^{+}, \mathrm{K}^{+}$, or $\mathrm{Cs}^{+}$. Only four bulk anions are considered extractable: nitrate, hydroxide, nitrite, and chloride. Among the other relevant anions, it was determined in earlier works that carbonate, fluoride, sulfate, and aluminate were not extractable enough to

Table 5. Species and formation constants used for the CSSX model in this work $^{a}$

\begin{tabular}{cc}
\hline Species & $\begin{array}{c}\text { Formation constant } \\
\log _{\mathbf{1 0}} \boldsymbol{K}\end{array}$ \\
\hline $\mathrm{CsNO}_{3}$ Calix & $3.656 \pm 0.029$ \\
$\left(\mathrm{CsNO}_{3}\right)_{2}$ Calix & $7.681 \pm 0.084$ \\
$\mathrm{CsOHCalix}$ & $3.292 \pm 0.016$ \\
$\mathrm{CsNO}_{2} \mathrm{Calix}$ & $3.166 \pm 0.013$ \\
$\mathrm{CsClCalix}_{\mathrm{KNO}} \mathrm{Calix}$ & $2.709 \pm 0.013$ \\
$\mathrm{KOHCalix}$ & $1.427 \pm 0.016$ \\
$\mathrm{KNO}_{2} \mathrm{Calix}$ & $1.385 \pm 0.017$ \\
$\mathrm{KClCalix}$ & $1.135 \pm 0.015$ \\
$\mathrm{NaOH} \mathrm{OH}$ & $0.649 \pm 0.014$ \\
$\mathrm{NaNO}_{3} \mathrm{Calix}$ & $-0.805 \pm 0.036$ \\
$\mathrm{NaNO}_{2} \mathrm{Calix}$ & $-0.803 \pm 0.041$ \\
$\mathrm{NaClCalix}$ & $-0.892 \pm 0.024$ \\
\hline
\end{tabular}

${ }^{a}$ Species are all formed in the organic phase. Formation constants are calculated on the molarity scale and are corrected to infinite dilution in water at $25^{\circ} \mathrm{C}$. 
participate in any organic complexes [16]. Two other anions of interest, citrate and phosphate, both bearing a -3 charge, are very hydrophilic and are considered to remain in the aqueous phase. These anions were included as only aqueous species to account for bulk ionic strength. Altogether, the model currently encompasses 3 cations and 10 anions, constituting the main waste components as shown below in Table 6, though fewer than the number of species stated for each tank. Ions at very low concentrations are ignored. Although further work on the model is desirable in terms of adding other ions that might be extractable (e.g., $\mathrm{Rb}^{+}$, dibutylphosphate, 4-sec-butylphenolate, and $\mathrm{TcO}_{4}{ }^{-}$), allowing temperature variation, and responding to changes in modifier concentration, for example, the currently parameterized model is considered useful for the present predictive purpose. For further details on the program and tables of fixed parameters (such as Pitzer's), the reader is referred to previous reports [16-18].

The values of $D_{\mathrm{Cs}}$ predicted by the model for the eight Hanford simulants are given in Table 7 . The model was run assuming an $\mathrm{O} / \mathrm{A}$ volume ratio of 0.33 and using the ionic composition specified in Table 6 , equilibrium constants shown in Table 5, and fixed activity and molar-volume parameters reported elsewhere [16]. As expected, the model predicts a strong correlation between the concentration of potassium and the value of the cesium distribution ratio. All values of $D_{\mathrm{Cs}}$ are in fact much lower than the value of 14 for the average SRS waste but are still sufficient to attain a CF value of at least 5 . Higher CFs could be attained in most cases, but it would likely be difficult to achieve CFs in the more desirable range of 10-15 for the two wastes with the highest potassium levels (\#3 and \#6).

Although the predicted cesium distribution ratios thus appear reasonable, it was nevertheless felt that experimental validation of the model for the Hanford feeds was advisable. The model was parameterized using data for the extraction of single potassium salts at concentrations as high as $1 \mathrm{M}$, but as pointed out in the Introduction, it was never validated with actual wastes or simulants with concentrations of potassium higher than respectively $40 \mathrm{mM}$ or $100 \mathrm{mM}$. Potassium loading of the calixarene will continue to increase as the aqueous potassium concentration is further increased. The concomitant decrease in $D_{\mathrm{Cs}}$ is predicted to be significantly below the range in which the CSSX solvent has been tested and where process goals could be compromised. Because high loading of solvent-extraction systems can often be accompanied by changes in speciation and distribution behavior, it was concluded that validation of the model for selected Hanford simulants was necessary to propose reliable distribution ratios as a basis for a conceptual flowsheet. Four different simulants (\#3, \#6, \#7, and \#8; see Table 6) were selected to bracket especially the range of potassium concentrations in the Hanford simulants but also to bracket the hydroxide and nitrate concentrations, known to be the most important anions in the equilibrium shown in Equation 2 (see Table 5). 
Table 6. Hanford waste feed compositions used in the model

\begin{tabular}{lcccccccccccccc}
\hline & {$\left[\mathrm{Na}^{+}\right]$} & {$\left[\mathrm{K}^{+}\right]$} & {$\left[\mathrm{Cs}^{+}\right]$} & {$\left[\mathrm{NO}_{3}{ }^{-}\right]$} & {$\left[\mathrm{Cl}{ }^{-}\right]$} & {$\left[\mathrm{NO}_{2}^{-}\right]$} & {$[\mathrm{OH}]$} & {$\left[\mathrm{F}^{-}\right]$} & {$\left[\mathrm{Citrate}^{3-}\right]$} & {$\left[\mathrm{PO}_{4}{ }^{3-}\right]$} & {$\left[\mathrm{SO}_{4}{ }^{2-}\right]$} & {$\left[\mathrm{CO}_{3}{ }^{2-}\right]$} & {$\left[\mathrm{Al}_{\left.(\mathrm{OH})_{4}\right]^{*}}\right.$} \\
\hline Simulant \#1 & 6.00 & 0.1170 & $5.75 \mathrm{E}-05$ & 2.38 & 0.0936 & 0.96 & 1.12 & 0.02370 & 0.0393 & 0.0474 & 0.0437 & 0.360 & 0.4722575 \\
Simulant \#2 & 6.00 & 0.0873 & $7.57 \mathrm{E}-05$ & 1.89 & 0.1080 & 1.45 & 1.41 & 0.00159 & 0.0230 & 0.0215 & 0.0202 & 0.202 & 0.6498857 \\
Simulant \#3 & 6.00 & 0.1470 & $8.98 \mathrm{E}-05$ & 2.82 & 0.0548 & 0.68 & 1.04 & 0.03070 & 0.0230 & 0.0432 & 0.0746 & 0.405 & 0.3637898 \\
Simulant\#4 & 6.00 & 0.0947 & $7.17 \mathrm{E}-05$ & 1.76 & 0.1080 & 1.35 & 0.96 & 0.02610 & 0.0683 & 0.0403 & 0.0403 & 0.436 & 0.6122717 \\
Simulant \#5 & 6.00 & 0.0680 & $7.75 \mathrm{E}-05$ & 1.74 & 0.1410 & 1.56 & 1.26 & 0.00542 & 0.0482 & 0.0294 & 0.0419 & 0.288 & 0.4690575 \\
Simulant \#6 & 6.00 & 0.1740 & $5.82 \mathrm{E}-05$ & 1.90 & 0.0940 & 1.17 & 1.45 & 0.01280 & 0.0325 & 0.0134 & 0.0322 & 0.367 & 0.6111582 \\
Simulant \#7 & 6.00 & 0.0749 & $2.03 \mathrm{E}-04$ & 2.33 & 0.0589 & 0.92 & 0.96 & 0.02920 & 0.0257 & 0.0393 & 0.1190 & 0.481 & 0.3820030 \\
Simulant \#8 & 6.00 & 0.0534 & $7.96 \mathrm{E}-05$ & 1.45 & 0.1010 & 1.15 & 1.74 & 0.01330 & 0.0127 & 0.0193 & 0.0457 & 0.373 & 0.6657796 \\
\hline
\end{tabular}

*These concentrations of aluminate are somewhat different than those presented in Table 1 to ensure the global mass balance. 
Table 7. Predicted $D_{\mathrm{Cs}}$ values using the CSSX model compared with experimental results

\begin{tabular}{cccc}
\hline Simulant & {$\left[\mathrm{K}^{+}\right](\mathrm{M})$} & Predicted $D_{\mathrm{Cs}}$ & Observed $D_{\mathrm{Cs}}{ }^{a}$ \\
\hline$\# 1$ & 0.1170 & 4.22 & \\
$\# 2$ & 0.0873 & 5.28 & \\
$\# 3$ & 0.1470 & 3.82 & 4.02 \\
$\# 4$ & 0.0947 & 4.67 & \\
$\# 5$ & 0.0680 & 5.87 & \\
$\# 6$ & 0.1740 & 3.20 & 3.56 \\
$\# 7$ & 0.0749 & 6.05 & 6.00 \\
$\# 8$ & 0.0534 & 7.26 & 8.50 \\
\hline
\end{tabular}

${ }^{a}$ Observed values taken as an average of duplicates in Table 8 for the first extraction contact with each of the four simulants tested.

\subsection{EXPERIMENTAL DISTRIBUTION RESULTS}

Simulants \#3, \#6, \#7, and \#8 were tested with the current CSSX solvent in use at the SRS. As discussed in the Introduction, it was also desirable to test the simulants with two variations of an improved CSSX solvent employing BEHBCalixC6 together with a more effective stripping method, as detailed in the subsections below. The tests with the current CSSX solvent were run in duplicates. Because of the small amount of BEHBCalixC6 available, the tests with this ligand were not duplicated. In the manner of sequential batch testing outlined earlier [4], the tests were conducted as $\mathrm{E}_{2} \mathrm{~S}_{2} \mathrm{~S}_{4}$ crosscurrent contacts. That is, a single volume of solvent undergoes two extractions, two scrubs, and four strips in sequence with fresh aqueous phases for each contact. All contacts were performed at $25{ }^{\circ} \mathrm{C}$ at $\mathrm{O}$ :A ratios of $1 / 3$ (extraction), 5 (scrubbing), and 5 (stripping). These conditions represent an ambitious contacting protocol that would achieve the most desired CF of 15 and, with two successive extraction contacts, involves a more severe loading effect than is likely to be encountered in a process. For example, using Simulant \#7, which has the highest Cs concentration $\left(2.27 \times 10^{-4} \mathrm{M}\right)$, a cesium loading of $10.8 \%$ of the calixarene was obtained. Such contacting data can be used for subsequent flowsheet calculations.

\subsubsection{Tests with the Current CSSX Solvent}

Results for $\mathrm{E}_{2} \mathrm{~S}_{2} \mathrm{~S}_{4}$ tests conducted for the current CSSX solvent with the four selected Hanford simulants are shown in Table 8. Duplicates were in good agreement, indicating consistency of technique and absence of sources of random error such as entrainment, temperature fluctuation, and nonequilibrium. Loading effects, which would be indicated by a large drop in $D_{\mathrm{Cs}}$ on the second extraction contact, are minor. This follows from the generally low cesium concentrations in the feed, giving a maximum of $6.5 \%$ cesium loading of the calixarene per contact (for Simulant \#7). Potassium loading would be high in each case and constant from contact to contact, as the aqueous potassium concentrations are much greater than the calixarene concentration. As expected from the modeling, extraction $D_{\mathrm{Cs}}$ values fall as potassium concentration in the feed increases. 
Table 7 shows that the model predictions are sufficiently reliable at high potassium concentrations. In particular, the standard error between the predicted and observed $D_{\mathrm{Cs}}$ values is found to be $\pm 11 \%$ for the four simulants tested. The predicted $D_{\mathrm{Cs}}$ values are systematically low, however, being an average of $7 \%$ lower than the corresponding experimental values. This would make flowsheet calculations slightly more conservative for the four simulants not tested.

Despite the variation of the concentrations of cesium, potassium, nitrate, and hydroxide, it may be seen that the performance of the scrub and strip stages is essentially the same from simulant to simulant. Moreover, scrubbing and stripping performance is essentially the same as that obtained for the average SRS waste [6], where the $D_{\mathrm{Cs}}$ values for the two sequential scrubs are 1.14 and 1.35 , and stripping $D_{\mathrm{Cs}}$ values decrease from 0.116 on the first strip to 0.052 on the fourth strip.

Table 8. Batch contacting results $\left(D_{\mathrm{Cs}}\right)$ for the current CSSX solvent and four Hanford simulants ${ }^{a}$

\begin{tabular}{lcccccccc}
\hline Stage & \multicolumn{2}{c}{ Simulant \#3 } & \multicolumn{2}{c}{ Simulant \#6 } & \multicolumn{2}{c}{ Simulant \#7 } & \multicolumn{2}{c}{ Simulant \#8 } \\
\hline Extraction 1 & 4.04 & 3.99 & 3.57 & 3.55 & 5.98 & 6.01 & 8.42 & 8.58 \\
Extraction 2 & 3.90 & 3.96 & 3.81 & 3.47 & 5.88 & 5.87 & 8.40 & 8.40 \\
Scrub 1 & 1.22 & 1.27 & 1.20 & 1.17 & 1.12 & 1.12 & 1.09 & 1.10 \\
Scrub 2 & 1.27 & 1.27 & 1.27 & 1.36 & 1.21 & 1.21 & 1.31 & 1.26 \\
Strip 1 & 0.094 & 0.097 & 0.090 & 0.090 & 0.120 & 0.125 & 0.102 & 0.101 \\
Strip 2 & 0.071 & 0.071 & 0.067 & 0.065 & 0.084 & 0.086 & 0.072 & 0.071 \\
Strip 3 & 0.059 & 0.058 & 0.056 & 0.057 & 0.064 & 0.065 & 0.063 & 0.057 \\
Strip 4 & 0.055 & 0.055 & 0.054 & 0.053 & 0.058 & 0.056 & 0.054 & 0.055 \\
\hline$\left[\mathrm{K}^{+}\right](\mathrm{M})$ & \multicolumn{2}{c}{0.147} & \multicolumn{2}{c}{0.174} & 0.0749 & 0.0534
\end{tabular}

${ }^{a}$ A single solvent sample was contacted in sequence with fresh aqueous phases at $25{ }^{\circ} \mathrm{C}$. The solvent consisted of $0.007 \mathrm{M}$ BOBCalixC6, 0.75 M Cs-7SB modifier, and $0.003 \mathrm{M}$ tri$n$-octylamine in Isopar L diluent. Scrub solutions were $50 \mathrm{mM} \mathrm{HNO}_{3}$, and strip solutions were $1 \mathrm{mM} \mathrm{HNO}$. O:A ratios were 1/3 (extraction), 5 (scrubbing), and 5 (stripping). Each test was run in duplicate, as indicated by two columns of distribution ratios $\left(D_{\mathrm{Cs}}\right)$ for each simulant.

\subsubsection{Batch Performance of Alternative CSSX Solvents and Improved Stripping Method}

Markedly improved overall extraction and stripping performance was found to be possible with an alternative CSSX solvent system used with boric acid stripping. Results for $\mathrm{E}_{2} \mathrm{~S}_{2} \mathrm{~S}_{4}$ tests conducted for two alternative CSSX solvents with the four selected Hanford simulants are shown in Table 9. Both solvents employed the soluble calixarene BEHBCalixC6 [21] at $20 \mathrm{mM}$ plus $0.75 \mathrm{M}$ Cs-7SB modifier and either $3 \mathrm{mM}$ TOA or $3 \mathrm{mM}$ LIX 79 guanidine suppressor in Isopar L diluent. In comparison with the performance of the current CSSX solvent, extraction $D_{\mathrm{Cs}}$ values for the alternative solvent systems tripled (factor of $3.03 \pm 0.06$ ), irrespective of the simulant or suppressor used. Following recent improvements in stripping methodology [19,20], scrubbing was carried out with $0.1 \mathrm{M} \mathrm{NaOH}$ at $\mathrm{O}: \mathrm{A}=5$ and stripping was carried out with $10 \mathrm{mM}$ boric acid at $\mathrm{O}: \mathrm{A}=5$. Scrub $D_{\mathrm{Cs}}$ values shown in Table 9 were large enough that 
a lower $\mathrm{NaOH}$ scrub concentration might be considered. Compared with the current CSSX system, stripping performance for the solvent containing TOA was excellent, roughly an order of magnitude better on the first strip and 25-fold better on successive strips. This comparison is illustrated graphically in Figure 1. The comparison makes it clear that the TOA alternative CSSX solvent system and stripping method can overcome the limitations posed by the high potassium concentration in the Hanford waste feeds, even outperforming the current CSSX flowsheet in use at the SRS.

The LIX 79 guanidinium suppressor was also tested, as it had earlier been found to give even better stripping performance than TOA for SRS type waste [19,20]. However, Table 9 shows that stripping with the guanidine suppressor was poor under the present conditions, reminiscent of the behavior obtained without any suppressor [4,25-27]. Currently, the reason for the failure of the guanidine suppressor is not known. However, the preliminary solvent conditioning with acid, base, and water used here was not employed in the previous work. A reasonable hypothesis is that the guanidine was either precipitated or lost to the aqueous phase in the wash steps used here. Further investigation is needed.

Table 9. Batch contacting results for two alternative CSSX solvents and four Hanford simulants ${ }^{a}$

\begin{tabular}{lrrrrrrrr}
\hline Stage & \multicolumn{2}{c}{ Simulant \#3 } & \multicolumn{2}{c}{ Simulant \#6 } & \multicolumn{2}{c}{ Simulant \#7 } & \multicolumn{2}{c}{ Simulant \#8 } \\
\hline & \multicolumn{1}{c}{ TOA } & \multicolumn{1}{c}{ Gua } & \multicolumn{1}{c}{ TOA } & \multicolumn{1}{c}{ Gua } & \multicolumn{1}{c}{ TOA } & \multicolumn{1}{c}{ Gua } & \multicolumn{1}{c}{ TOA } & Gua \\
\hline Extraction 1 & 12.17 & 11.93 & 10.57 & 10.57 & 18.56 & 18.21 & 26.50 & 26.18 \\
Extraction 2 & 12.07 & 10.98 & 9.79 & 9.92 & 16.76 & 16.15 & 23.05 & 22.92 \\
Scrub 1 & 4.46 & 4.45 & 4.40 & 4.21 & 4.02 & 4.10 & 4.18 & 3.95 \\
Scrub 2 & 3.70 & 3.33 & 3.36 & 3.75 & 3.07 & 3.24 & 3.64 & 3.53 \\
Strip 1 & 0.010 & 0.346 & 0.011 & 0.352 & 0.017 & 0.084 & 0.0087 & 0.339 \\
Strip 2 & 0.001 & 0.615 & 0.0010 & 0.452 & 0.0019 & 0.281 & 0.0009 & 0.655 \\
Strip 3 & 0.001 & 0.513 & 0.0007 & 0.295 & 0.0006 & 0.335 & 0.0006 & 0.563 \\
Strip 4 & 0.002 & 0.370 & 0.0007 & 0.114 & 0.0009 & 0.224 & 0.0009 & 0.398 \\
\hline$\left[\mathrm{K}^{+}\right](\mathrm{M})$ & \multicolumn{2}{c}{0.147} & \multicolumn{2}{c}{0.174} & 0.0749 & 0.0534
\end{tabular}

${ }^{a} \mathrm{~A}$ single solvent sample was contacted in sequence with fresh aqueous phases at $25{ }^{\circ} \mathrm{C}$. The solvent consisted of $0.020 \mathrm{M}$ BEHBCalixC6, 0.75 M Cs-7SB modifier, and either $0.003 \mathrm{M}$ tri- $n$-octylamine (TOA) or $0.003 \mathrm{M}$ LIX 79 guanidine (Gua) in Isopar L diluent. Scrub solutions were $0.1 \mathrm{M} \mathrm{NaOH}$, and strip solutions were $10 \mathrm{mM}$ boric acid. O:A ratios were 1/3 (extraction), 5 (scrubbing), and 5 (stripping). Two columns of distribution ratios $\left(D_{\mathrm{Cs}}\right)$ for each simulant correspond to each of the different solvent modifiers employed. 


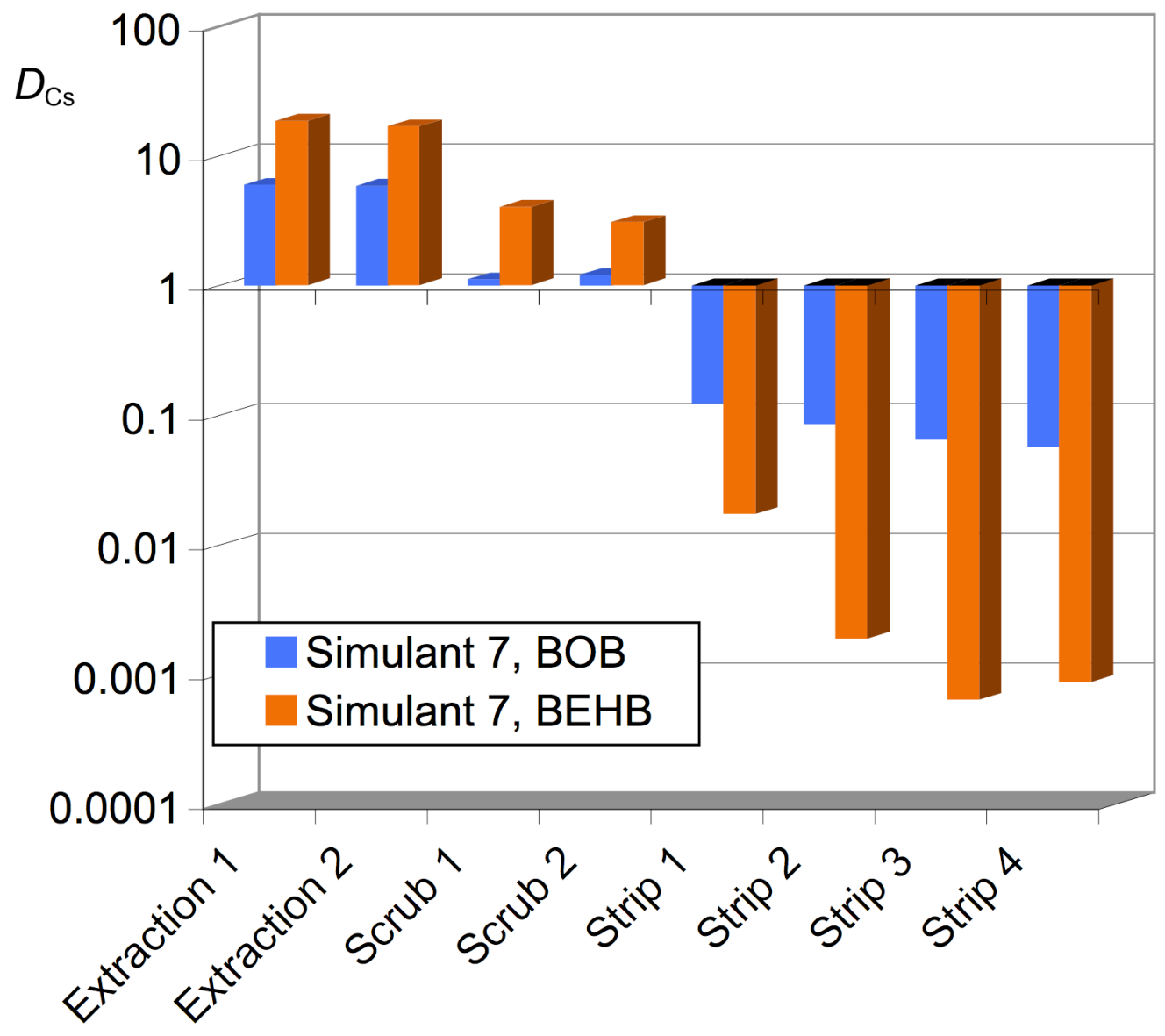

Figure 1. Comparison of extraction/scrub/strip batch performance of the current CSSX solvent (BOB) with the alternative solvent (BEHB). The data are taken from Tables 8 and 9 for Simulant \#7. The BEHB system contains TOA as the suppressor.

\subsection{PROCESS ENGINEERING}

\subsubsection{Flowsheet Design}

Flowsheet design was performed using a computer simulation based on the SEPHIS (Solvent Extraction Processes Having Interacting Solutes) code that was developed at ORNL [28]. Basic stagecalculation equations used in SEPHIS were utilized to determine the number of extraction and stripping stages required to achieve target decontamination and concentration factors, the former being the quotient of the Cs concentration in the feed divided by the concentration in the raffinate, the latter being the quotient of the product stream Cs concentration divided by the feed stream concentration. Independent variables in the calculations were the feed Cs concentration; the Cs concentration in the stripped (and recycled) solvent; the number of scrubbing stages; the decontamination factor (DF); the concentration 
factor (CF); the O:A flow ratios in extraction, scrubbing, and stripping sections of the flowsheet; and the Cs distribution ratios under extraction, scrubbing, and stripping conditions.

Flowsheet calculations were performed for all combinations of solvent (BOBCalixC6- and BEHBCalixC6-based) and the four simulants for which distribution ratios were determined. The four simulants bracket the highest and lowest $D_{\mathrm{Cs}}$ values, obviating the need to run all eight simulant cases. Results are based on use of the distribution ratios listed in Table 10, which are averages obtained from the $\mathrm{E}_{2} \mathrm{~S}_{2} \mathrm{~S}_{4}$ test results. Various cases were run to demonstrate the effect of different DF and CF scenarios. The calculations employed arbitrary, but reasonable, stage efficiencies of $80 \%$ to estimate the "actual" number of stages shown; these may be compared with the slightly greater "theoretical" stages assuming that stage efficiencies are $100 \%$ (i.e., running at equilibrium). Four scrub stages were arbitrarily assumed, though two are used at the SRS and presumed sufficient [8-10]. No wash stages were included, as they would not be expected to influence the results; however, two wash stages with $10 \mathrm{mM} \mathrm{NaOH}$, as used at the SRS, are likely necessary for long-term process stability. Results of the flowsheet calculations are presented in Tables 11 and 12. Under the assumptions made, the calculations show that up to 41 stages of contactors will be needed to achieve DF and CF targets of respectively 5000 and 5 for the current CSSX solvent (BOBCalixC6-based) and the most challenging waste composition (\#6). The magnitude of CF is the more influential goal parameter. If the $\mathrm{CF}$ requirement is relaxed to 2 , the number of stages drops to 31, whereas if the CF requirement increases to 15 , the number of stages more than doubles to 74 . Dropping the CF requirement compromises IPS goals, however, as treated LAW will be returned to the tanks, making reduction of the volume of the return flow highly desirable. If the required DF is raised to 40,000 , the number of stages increases only to 45 . While the number of stages is fairly high if a limited footprint is available, considerable improvement in solvent performance is predicted if the BEHBCalixC6-based solvent system and stripping method is employed (Table 12). In this case, the most challenging waste feed (\#6) and the most ambitious goals $(\mathrm{DF}=40,000$ and $\mathrm{CF}=15)$ require only 19 stages. Additional flowsheet cases were calculated for both BOB and BEHB solvents with the minimum $\mathrm{DF}$ values given in Table 1 and $\mathrm{CF}=5$; this would allow the elimination of only one or two stages compared with using the uniform DF value of 5000 with $\mathrm{CF}=5$.

Table 10. Cesium distribution ratios used in flowsheet simulations

\begin{tabular}{cccc}
\hline Solvent & Simulant & $D_{\mathrm{Cs}}$ Extraction & $D_{\mathrm{Cs}}$ Stripping \\
\hline BOB & 3 & 4 & $7.00 \mathrm{E}-02$ \\
BOB & 6 & 3.7 & $7.00 \mathrm{E}-02$ \\
BOB & 7 & 5.9 & $8.00 \mathrm{E}-02$ \\
BOB & 8 & 8.4 & $7.00 \mathrm{E}-02$ \\
BEHB & 3 & 12 & $1.00 \mathrm{E}-03$ \\
BEHB & 6 & 10 & $1.00 \mathrm{E}-03$ \\
BEHB & 7 & 17 & $2.00 \mathrm{E}-03$ \\
BEHB & 8 & 24 & $1.00 \mathrm{E}-03$ \\
\hline
\end{tabular}


Table 11. Flowsheet calculation results for BOBCalixC6-based solvent cases

\begin{tabular}{|c|c|c|c|c|c|c|c|c|c|c|c|c|c|}
\hline Solvent & Simulant & $\mathrm{CF}$ & $\mathrm{DF}$ & $\begin{array}{l}\text { Solvent-to- } \\
\text { feed ratio }\end{array}$ & $\begin{array}{l}\text { Solvent-to- } \\
\text { scrub ratio }\end{array}$ & $\begin{array}{l}\text { Solvent-to- } \\
\text { strip ratio }\end{array}$ & $\begin{array}{l}\text { Theor. } \\
\text { extraction } \\
\text { stages }\end{array}$ & $\begin{array}{l}\text { Theor. } \\
\text { stripping } \\
\text { stages }\end{array}$ & $\begin{array}{l}\text { Actual } \\
\text { extraction } \\
\text { stages }\end{array}$ & $\begin{array}{c}\text { Actual } \\
\text { stripping } \\
\text { stages }\end{array}$ & $\begin{array}{c}\text { Stage } \\
\text { efficiency } \\
\%\end{array}$ & $\begin{array}{l}\text { Scrubbing } \\
\text { stages }\end{array}$ & $\begin{array}{l}\text { Total actual } \\
\text { stages }\end{array}$ \\
\hline BOB & 3 & 2 & 5000 & 0.9 & 5 & 1.8 & 9 & 13 & 11 & 16 & 80 & 4 & 31 \\
\hline $\mathrm{BOB}$ & 3 & 5 & 5000 & 0.65 & 5 & 3.25 & 11 & 18 & 14 & 22 & 80 & 4 & 40 \\
\hline BOB & 3 & 15 & 5000 & 0.45 & 5 & 6.75 & 18 & 34 & 23 & 43 & 80 & 4 & 70 \\
\hline BOB & 3 & 2 & 40000 & 1 & 5 & 2 & 10 & 13 & 13 & 16 & 80 & 4 & 33 \\
\hline ВOB & 3 & 5 & 40000 & 0.7 & 5 & 3.5 & 13 & 18 & 16 & 23 & 80 & 4 & 43 \\
\hline BOB & 3 & 15 & 40000 & 0.45 & 5 & 6.75 & 23 & 34 & 29 & 43 & 80 & 4 & 76 \\
\hline BOB & 6 & 2 & 5000 & 0.95 & 5 & 1.9 & 9 & 13 & 11 & 16 & 80 & 4 & 31 \\
\hline $\mathbf{B O B}^{a}$ & 6 & 5 & 5000 & 0.7 & 5 & 3.5 & 12 & 18 & 14 & 23 & 80 & 4 & 41 \\
\hline ВОВ & 6 & 15 & 5000 & 0.45 & 5 & 6.75 & 22 & 34 & 27 & 43 & 80 & 4 & 74 \\
\hline BOB & 6 & 2 & 40000 & 1.1 & 5 & 2.2 & 10 & 14 & 13 & 17 & 80 & 4 & 34 \\
\hline BOB & 6 & 5 & 40000 & 0.75 & 5 & 3.75 & 14 & 19 & 17 & 24 & 80 & 4 & 45 \\
\hline BOB & 6 & 15 & 40000 & 0.47 & 5 & 7.05 & 25 & 36 & 32 & 45 & 80 & 4 & 81 \\
\hline BOB & 7 & 2 & 5000 & 0.65 & 5 & 1.3 & 8 & 12 & 9 & 15 & 80 & 4 & 28 \\
\hline BOB & 7 & 5 & 5000 & 0.47 & 5 & 2.35 & 10 & 16 & 12 & 20 & 80 & 4 & 36 \\
\hline BOB & 7 & 15 & 5000 & 0.31 & 5 & 4.65 & 16 & 27 & 20 & 33 & 80 & 4 & 57 \\
\hline BOB & 7 & 2 & 40000 & 0.75 & 5 & 1.5 & 9 & 12 & 11 & 15 & 80 & 4 & 30 \\
\hline BOB & 7 & 5 & 40000 & 0.5 & 5 & 2.5 & 12 & 16 & 14 & 20 & 80 & 4 & 38 \\
\hline BOB & 7 & 15 & 40000 & 0.33 & 5 & 4.95 & 18 & 28 & 23 & 35 & 80 & 4 & 62 \\
\hline BOB & 8 & 2 & 5000 & 0.5 & 5 & 1 & 7 & 10 & 9 & 13 & 80 & 4 & 26 \\
\hline BOB & 8 & 5 & 5000 & 0.4 & 5 & 2 & 8 & 14 & 10 & 17 & 80 & 4 & 31 \\
\hline BOB & 8 & 15 & 5000 & 0.25 & 5 & 3.75 & 12 & 20 & 15 & 25 & 80 & 4 & 44 \\
\hline BOB & 8 & 2 & 40000 & 0.65 & 5 & 1.3 & 7 & 11 & 9 & 14 & 80 & 4 & 27 \\
\hline BOB & 8 & 5 & 40000 & 0.43 & 5 & 2.15 & 9 & 14 & 12 & 18 & 80 & 4 & 34 \\
\hline BOB & 8 & 15 & 40000 & 0.27 & 5 & 4.05 & 14 & 21 & 18 & 26 & 80 & 4 & 48 \\
\hline
\end{tabular}

${ }^{a}$ Case selected for contactor sizing (see Section 3.3.2). 
Table 12. Flowsheet calculation results for BEHBCalixC6-based solvent cases

\begin{tabular}{|c|c|c|c|c|c|c|c|c|c|c|c|c|c|}
\hline Solvent & Simulant & $\mathrm{CF}$ & $\mathrm{DF}$ & $\begin{array}{l}\text { Solvent-to- } \\
\text { feed ratio }\end{array}$ & $\begin{array}{l}\text { Solvent-to- } \\
\text { scrub ratio }\end{array}$ & $\begin{array}{l}\text { Solvent-to- } \\
\text { strip ratio }\end{array}$ & $\begin{array}{l}\text { Theor. } \\
\text { extraction } \\
\text { stages }\end{array}$ & $\begin{array}{c}\text { Theor. } \\
\text { stripping } \\
\text { stages }\end{array}$ & $\begin{array}{c}\text { Actual } \\
\text { extraction } \\
\text { stages }\end{array}$ & $\begin{array}{c}\text { Actual } \\
\text { stripping } \\
\text { stages }\end{array}$ & $\begin{array}{c}\text { Stage } \\
\text { efficiency } \\
\%\end{array}$ & $\begin{array}{c}\text { Scrubbing } \\
\text { stages }\end{array}$ & $\begin{array}{c}\text { Total actual } \\
\text { stages }\end{array}$ \\
\hline BEHB & 3 & 2 & 5000 & 1.25 & 5 & 2.5 & 4 & 5 & 5 & 3 & 80 & 4 & 12 \\
\hline BEHB & 3 & 5 & 5000 & 0.75 & 5 & 3.75 & 5 & 5 & 6 & 6 & 80 & 4 & 16 \\
\hline BEHB & 3 & 15 & 5000 & 0.6 & 5 & 9 & 5 & 6 & 6 & 7 & 80 & 4 & 17 \\
\hline BEHB & 3 & 2 & 40000 & 0.8 & 5 & 1.6 & 6 & 4 & 7 & 5 & 80 & 4 & 16 \\
\hline BEHB & 3 & 5 & 40000 & 1 & 5 & 5 & 5 & 5 & 6 & 6 & 80 & 4 & 16 \\
\hline BEHB & 3 & 15 & 40000 & 1 & 5 & 15 & 5 & 6 & 6 & 8 & 80 & 4 & 18 \\
\hline BEHB & 6 & 2 & 5000 & 1.25 & 5 & 2.5 & 4 & 5 & 5 & 6 & 80 & 4 & 15 \\
\hline BEHB & 6 & 5 & 5000 & 0.75 & 5 & 3.75 & 5 & 5 & 6 & 6 & 80 & 4 & 16 \\
\hline BEHB & 6 & 15 & 5000 & 0.6 & 5 & 9 & 6 & 6 & 7 & 7 & 80 & 4 & 18 \\
\hline BEHB & 6 & 2 & 40000 & 0.8 & 5 & 1.6 & 6 & 4 & 8 & 5 & 80 & 4 & 17 \\
\hline BEHB & 6 & 5 & 40000 & 1 & 5 & 5 & 6 & 5 & 7 & 6 & 80 & 4 & 17 \\
\hline BEHB & 6 & 15 & 40000 & 0.7 & 5 & 10.5 & 7 & 6 & 8 & 7 & 80 & 4 & 19 \\
\hline BEHB & 7 & 2 & 5000 & 1.25 & 5 & 2.5 & 4 & 5 & 4 & 6 & 80 & 4 & 14 \\
\hline BEHB & 7 & 5 & 5000 & 0.7 & 5 & 3.5 & 4 & 6 & 5 & 7 & 80 & 4 & 16 \\
\hline BEHB & 7 & 15 & 5000 & 0.6 & 5 & 9 & 4 & 7 & 5 & 8 & 80 & 4 & 17 \\
\hline BEHB & 7 & 2 & 40000 & 0.7 & 5 & 1.4 & 5 & 5 & 6 & 6 & 80 & 4 & 16 \\
\hline BEHB & 7 & 5 & 40000 & 0.7 & 5 & 3.5 & 5 & 6 & 6 & 7 & 80 & 4 & 17 \\
\hline BEHB & 7 & 15 & 40000 & 0.6 & 5 & 3 & 5 & 7 & 7 & 8 & 80 & 4 & 19 \\
\hline BEHB & 8 & 2 & 5000 & 0.75 & 5 & 1.5 & 4 & 4 & 4 & 5 & 80 & 4 & 13 \\
\hline BEHB & 8 & 5 & 5000 & 0.75 & 5 & 3.75 & 4 & 5 & 4 & 6 & 80 & 4 & 14 \\
\hline BEHB & 8 & 15 & 5000 & 0.7 & 5 & 10.5 & 4 & 6 & 4 & 7 & 80 & 4 & 15 \\
\hline BEHB & 8 & 2 & 40000 & 0.6 & 5 & 1.2 & 5 & 4 & 6 & 5 & 80 & 4 & 15 \\
\hline BEHB & 8 & 5 & 40000 & 0.75 & 5 & 3.75 & 4 & 5 & 5 & 6 & 80 & 4 & 15 \\
\hline BEHB & 8 & 15 & 40000 & 0.6 & 5 & 9 & 5 & 6 & 6 & 7 & 80 & 4 & 17 \\
\hline
\end{tabular}




\subsubsection{Contactor Size Determinations}

To enable initial cost estimation, a general prediction of the size(s) of contactors required in a flowsheet capable of processing Hanford tank waste at a rate of $20.3 \mathrm{~L} / \mathrm{min}$. is needed. The generalized correlation for estimating the radius of a contactor rotor required for a given total throughput was utilized. This correlation is

$$
q=0.307 r^{2.443}
$$

where $q$ is the throughput in $\mathrm{m}^{3} / \mathrm{s}$ and $r$ is the rotor radius in meters [29]. This correlation was developed based on actual throughput data for contactors used in PUREX applications (i.e., contact of $30 \% \mathrm{v} / \mathrm{v}$ tri- $n$ butyl phosphate in a hydrocarbon diluent with aqueous nitric acid solutions). As values of properties best indicating phase separation are similar for the subject application and the application on which the correlation is based, it is expected that correlation is valid for the subject case. Dispersion numbers determined under extraction conditions for the subject application under are presented in Table 13; stripping condition results are presented in Table 14. Scrubbing results are similar to those for stripping and are not presented, as they do not limit overall process performance. Density and viscosity values applicable to the Hanford application are presented in Tables 15 and 16, respectively. It should be noted that detailed design of contactors for use in the flowsheets designed for the subject application cannot be performed using the dispersion numbers determined here, as the values observed are for phase ratios that differ from those found to be optimum with respect to throughput and stage-number requirement.

In collaboration with $\mathrm{CH} 2 \mathrm{MHill}$ staff, the flowsheet simulation results were reviewed, and conditions applicable to extraction of Simulant \#6 using BOBCalixC6-based solvent in a flowsheet having a DF of 5000 and a CF of 5 were selected as the basis for contactor sizing. (The applicable case is shown in bold type in Table 11.) On this basis together with the desired processing rate, the total throughputs required in the extraction, scrubbing, and stripping sections of the contactor cascade are $37.35 \mathrm{~L} / \mathrm{min} ., 17.05 \mathrm{~L} / \mathrm{min}$., and $18.27 \mathrm{~L} / \mathrm{min}$., respectively. Rearranging the sizing correlation to solve for rotor radius, the predicted rotor diameters required for processing in each section of the cascade, based on $100 \%$ capacity, are 15.8 $\mathrm{cm}$ (6.22 in.) in extraction, $11.46 \mathrm{~cm}$ (4.5 in.) in scrubbing, and $11.8 \mathrm{~cm}$ (4.65 in.) in stripping. More realistically, contactors sized to operate at $75 \%$ of capacity have rotor diameters of $17.8 \mathrm{~cm}(7.0 \mathrm{in}$.), 12.9 $\mathrm{cm}$ (5.0 in.), and $13.3 \mathrm{~cm}$ (5.23 in.) in extraction, scrubbing, and stripping, respectively. Based on these results, it appears feasible to utilize commercially available equipment having 5 in. diameter rotors in the scrubbing and stripping sections of the cascade. The next larger size of commercially available equipment has a $10 \mathrm{in}$. diameter rotor. The projected throughput of this equipment is approximately $120 \mathrm{~L} / \mathrm{min}$., which is about 3 times the required capacity in extraction. The disparity between available and needed capacities could result in decreased mixing in the mixing zone of the contactor, leading to poor mass-

transfer efficiency. Should the need arise to utilize commercial contactor equipment in the subject application, special consideration of this potential problem is advised. 
Table 13. Extraction-condition dispersion numbers

\begin{tabular}{cccc}
\hline Simulant & $\begin{array}{c}\text { Dispersion band height } \\
\mathrm{cm}\end{array}$ & $\begin{array}{c}\text { Break time } \\
\text { s }\end{array}$ & \begin{tabular}{c} 
Dispersion number \\
\hline 3
\end{tabular} \\
\hline 3 & 15.24 & 191 & $6.54 \mathrm{E}-04$ \\
3 & 15.24 & 175 & $7.12 \mathrm{E}-04$ \\
3 & 15.24 & 145 & $8.60 \mathrm{E}-04$ \\
3 & 15.24 & 151 & $8.26 \mathrm{E}-04$ \\
6 & 15.24 & 154 & $8.10 \mathrm{E}-04$ \\
6 & 15.24 & 170 & $7.33 \mathrm{E}-04$ \\
6 & 15.24 & 167 & $7.47 \mathrm{E}-04$ \\
6 & 15.24 & 159 & $7.85 \mathrm{E}-04$ \\
6 & 15.24 & 158 & $7.91 \mathrm{E}-04$ \\
7 & 15.24 & 153 & $8.16 \mathrm{E}-04$ \\
7 & 15.24 & 112 & $1.11 \mathrm{E}-03$ \\
7 & 15.24 & 162 & $7.68 \mathrm{E}-04$ \\
7 & 15.24 & 157 & $7.96 \mathrm{E}-04$ \\
7 & 15.24 & 155 & $8.04 \mathrm{E}-04$ \\
7 & 15.24 & 131 & $9.53 \mathrm{E}-04$ \\
8 & 15.24 & 136 & $9.17 \mathrm{E}-04$ \\
8 & 15.24 & 205 & $6.08 \mathrm{E}-04$ \\
8 & 15.24 & 198 & $6.30 \mathrm{E}-04$ \\
8 & 15.24 & 192 & $6.50 \mathrm{E}-04$ \\
8 & 15.24 & 196 & $6.38 \mathrm{E}-04$ \\
\hline
\end{tabular}

Table 14. Stripping-condition dispersion numbers

\begin{tabular}{cccc}
\hline Simulant & $\begin{array}{c}\text { Dispersion band height } \\
\mathrm{cm}\end{array}$ & $\begin{array}{c}\text { Break time } \\
\mathrm{s}\end{array}$ & Dispersion number \\
\hline 6 & 13.208 & 238 & $4.88 \mathrm{E}-04$ \\
6 & 13.208 & 240 & $4.84 \mathrm{E}-04$ \\
6 & 13.208 & 250 & $4.64 \mathrm{E}-04$ \\
6 & 13.208 & 242 & $4.80 \mathrm{E}-04$ \\
6 & 13.208 & 220 & $5.28 \mathrm{E}-04$ \\
8 & 13.208 & 163 & $7.12 \mathrm{E}-04$ \\
8 & 13.208 & 145 & $8.00 \mathrm{E}-04$ \\
8 & 13.208 & 150 & $7.74 \mathrm{E}-04$ \\
8 & 13.208 & 157 & $7.39 \mathrm{E}-04$ \\
8 & 13.208 & 160 & $7.25 \mathrm{E}-04$ \\
\hline
\end{tabular}


Table 15. Density-determination results $\left(25.2^{\circ} \mathrm{C}\right)$

Solution Description

Simulant \#3

Simulant \#6

Simulant \#7

Simulant \#8

BOBCalixC6-based solvent
Density, $\mathrm{g} / \mathrm{mL}$

1.284

1.279

1.287

1.278

0.853

Table 16. Viscosity-determination results $\left(25^{\circ} \mathrm{C}\right)$

\begin{tabular}{lc}
\hline \multicolumn{1}{c}{ Solution description } & Viscosity, cP \\
\hline Simulant \#3 & 3.00 \\
Simulant \#6 & 3.66 \\
Simulant \#7 & 3.02 \\
Simulant \#8 & 4.34 \\
BOBCalixC6-based solvent & 3.35 \\
Solvent after extraction of Simulant \#3 & 3.72 \\
Solvent after extraction of Simulant \#7 & 3.34 \\
Solvent after extract/scrub/strip from Simulant \#6 & 3.64 \\
Solvent after extract/scrub/strip from Simulant \#8 & 3.47 \\
\hline
\end{tabular}




\section{CONCLUSIONS}

It is concluded from batch distribution experiments, physical-property measurements, equilibrium modeling, flowsheet calculations, and contactor sizing that the CSSX process as currently employed for cesium removal from alkaline salt waste at the SRS is capable of treating similar Hanford tank feeds. Because of the higher potassium concentrations in the eight Hanford feed compositions examined, the cesium distribution ratios are depressed on extraction, an effect that was adequately predicted by the CSSX model. Flowsheet calculations showed that the lower cesium distribution ratios degraded overall performance, which still met minimum process goals, defined by a decontamination factor (DF) of 5000 and a concentration factor (CF) of 5, but with large numbers of stages. For the most challenging waste composition, 41 stages would be required. Higher DFs and CFs can be achieved with even more stages, but the CFs that can be achieved are limited. Commercial contacting equipment with rotor diameters of $10 \mathrm{in}$. for extraction and $5 \mathrm{in}$. for stripping would have the capacity to meet throughput requirements.

An alternative CSSX solvent used with a new stripping method was shown to markedly improve overall performance. The alternative solvent employs the more soluble extractant BEHBCalixC6 used at $20 \mathrm{mM}$. The new stripping method requires a scrub with $0.1 \mathrm{M} \mathrm{NaOH}$, which is followed by stripping with $10 \mathrm{mM}$ boric acid. Cesium distribution ratios are tripled on extraction and decimated on stripping, resulting in flowsheets with relatively few stages. For the most challenging waste composition, a DF of 5000 and $\mathrm{CF}$ of 5 could be obtained with 16 stages, which increases to only 19 to meet the more ambitious DF of 40,000 and CF of 15 . It may be noted that the performance of the CSSX process improvements exceeds the performance of the current CSSX process on the less challenging SRS waste (32 stages to achieve $\mathrm{DF}=40,000$ and $\mathrm{CF}=15$ ) and thus represents a viable multi-site technology option.

Potential future research and development investments that may add value include further development of a) the current CSSX process as applied to Hanford waste, b) the CSSX model, and c) the improved CSSX process. Regarding application of the current CSSX process to Hanford waste types, further engineering efforts would be needed for optimal contactor design. Improvements to the CSSX model are needed. In particular, it is desirable to correct for systematic error in high-potassium situations. It would be worthwhile to expand the model to include distribution of ions not already in the model, temperature variation, and concentration variation of solvent components. It would be helpful to reparameterize the model for an alternative solvent formulation with BEHBCalixC6 and also make the model capable of predicting scrub and strip performance. Perhaps the greatest dividends in research and development would be to further develop the improved CSSX process. Although the results herein are especially promising, a number of chemistry and engineering issues should be addressed. Toward solvent development, the question of whether a guanidine type compound could replace the TOA suppressor needs to be settled. The stability of the solvent needs to be ensured, especially if the TOA suppressor is replaced. The scrubbing and stripping methodology should be optimized. In particular, there is some latitude in selecting the strip solution following a scrub with dilute $\mathrm{NaOH}$ [20]. Boric acid is highly

effective and has special appeal if vitrification is the destination of the strip solution, which is not the case for the IPS. Hydraulics studies and contactor design will be needed. 
Overall, the CSSX process represents a viable technology for cesium removal from Hanford wastes. In its current formulation, however, the process is not as efficient with Hanford feeds as it is with SRS feeds, owing to the higher potassium levels in the Hanford feeds. Some R\&D investments in the engineering of the process and the CSSX model are desirable. An improved CSSX solvent formulation and scrub/strip method is highly promising but will need additional development and optimization. 


\section{REFERENCES}

[1] Moyer, B. A.; Birdwell, J. F., Jr.; Bonnesen, P. V.; Delmau, L. H. Use of Macrocycles in Nuclear-Waste Cleanup: A Real-World Application of a Calixcrown in Technology for the Separation of Cesium. In Macrocyclic Chemistry-Current Trends and Future; Gloe, K., Ed.; Springer: Dordrecht, 2005; pp. 383-405.

[2] Bonnesen, P. V.; Delmau, L. H.; Moyer, B. A.; Leonard, R. A. A Robust Alkaline-Side CSEX Solvent Suitable for Removing Cesium from Savannah River High Level Waste. Solvent Extr. Ion Exch. 2000, 18(6), 1079-1108.

[3] Leonard, R. A.; Conner, C. M.; Liberatore, W.; Sedlet, J.; Aase, S. B.; Vandegrift, G. F.; Delmau, L. H.; Bonnesen, P. V.; Moyer, B. A. Development of a Solvent Extraction Process for Cesium Removal from SRS Tank Waste. Sep. Sci. Technol. 2001, 36(5\&6), 743-766.

[4] Moyer, B. A.; Alexandratos, S. D.; Bonnesen, P. V.; Brown, G. M.; Caton, J. E., Jr.; Delmau, L. H.; Duchemin, C. R.; Haverlock, T. J.; Levitskaia, T. G.; Maskarinec, M. P.; Sloop, F. V., Jr.; Stine, C. L. Caustic-Side Solvent Extraction Chemical and Physical Properties: Progress in FY 2000 and FY 2001. Report ORNL/TM-2001/285; Oak Ridge National Laboratory, Oak Ridge, TN, February 2002.

[5] Klatt, L. N.; Birdwell, J. F., Jr.; Bonnesen, P. V.; Delmau, L. H.; Foote, L. J.; Lee, D. D.; Leonard, R. A.; Levitskaia, T. G.; Maskarinec, M. P.; Moyer, B. A. Caustic-Side Solvent Extraction Solvent-Composition Recommendations. ORNL/TM-2001/258; Oak Ridge National Laboratory, Oak Ridge, TN, January 2002.

[6] Delmau, L. H.; Birdwell, J. F., Jr.; Bonnesen, P. V.; Foote, L. J.; Haverlock, T. J.; Klatt, L. N.; Lee, D. D.; Leonard, R. A.; Levitskaia, T. G.; Maskarinec, M. P.; Moyer, B. A.; Sloop, F. V., Jr.; Tomkins, B. A. Caustic-Side Solvent Extraction: Chemical and Physical Properties of the Optimized Solvent. Report ORNL/TM-2002/190; Oak Ridge National Laboratory, Oak Ridge, TN, October 2002.

[7] Leonard, R. A.; Aase, S. B.; Arafat, H. A.; Conner, C.; Chamberlain, D. B.; Falkenberg, J. R.; Regalbuto, M. C.; Vandegrift, G. F. Experimental Verification of Caustic-Side Solvent Extraction for Removal of Cesium from Tank Waste. Solvent Extr. Ion Exch. 2003, 21(4), 505-526.

[8] Norato, M. A.; Beasley, M. H.; Campbell, S. G.; Coleman, A. D.; Geeting, M. W.; Guthrie, J. W.; Kennell, C. W.; Pierce, R. A.; Ryberg, R. C.; Walker, D. D.; Law, J. D.; Todd, T. A. Demonstration of the Caustic-Side Solvent Extraction Process for the Removal of Cs-137 from Savannah River Site High Level Waste. Sep. Sci. Technol. 2003, 38(12,13), 2647-2666.

[9] Walker, D. D.; Norato, M. A.; Campbell, S. G.; Crowder, M. L.; Fink, S. D.; Fondeur, F. F.; Geeting, M. W.; Kessinger, G. F.; Pierce, R. A. Cesium Removal from Savannah River Site Radioactive Waste Using the Caustic-Side Solvent Extraction (CSSX) Process. Sep. Sci. Technol. 2005, 40(1-3), 297-309.

[10] Dimenna, R. A.; Elder, H. H.; Fowler, J. R.; Fowler, R. C.; Gregory, M. V.; Hang, T.; Jacobs, R. A.; Paul, P. K.; Pike, J. A.; Rutland, P. L.; Smith, F. G. III; Subosits, S. G.; Taylor, G. A.; 
Campbell, S. G.; Washburn, F. A. Bases, Assumptions, and Results of the Flow Sheet Calculations for the Decision Phase Salt Disposition Alternatives. Report WSRC-RP-99-00006, Rev. 3; Westinghouse Savannah River Company, Aiken, South Carolina, May 2001.

[11] Moyer, B. A.; Bonnesen, P. V.; Sachleben, R. A.; Haverlock, T. J.; Presley, D. J.; Leonard, R. A.; Conner, C.; Lumetta, G. J.; Todd, T. A.; Wood, D. J. Fission Product Solvent Extraction. Proc. Efficient Separations and Processing Crosscutting Program 1998 Technical Exchange Meeting, Augusta, GA, March 17-19, 1998, pp. 49-55.

[12] Moyer, B. A.; Bonnesen, P. V.; Delmau, L. H.; Haverlock, T. J.; Sachleben, R. A.; Leonard, R. A.; Conner, C.; Lumetta, G. J. Solvent Extraction of Tc and Cs from Alkaline Nitrate Wastes. In Solvent Extraction for the 21st Century; Cox, M.; Hidalgo, M.; Valiente, M., Eds.; Society of Chemical Industry, London, 2001; Proc. Int. Solvent Extraction Conference (ISEC '99), Barcelona, Spain, July 11-16, 1999; Vol. 2, pp. 1365-1369.

[13] Peterson, R. A. Preparation of Simulated Waste Solutions for Solvent Extraction Testing. Report WSRC-RP-2000-00361; Westinghouse Savannah River Company, Aiken, SC, May 1, 2000.

[14] Sachleben, R. A.; Bonnesen, P. V.; Descazeaud, T.; Haverlock, T. J.; Urvoas, A.; Moyer, B. A. Surveying the Extraction of Cesium Nitrate by 1,3-Alternate Calix[4]arene Crown-6 Ethers in 1,2-Dichloroethane. Solvent Extr. Ion Exch. 1999, 17, 1445-1459.

[15] Bonnesen, P. V.; Delmau, L. H.; Moyer, B. A.; Lumetta, G. J. Development of Effective Solvent modifiers for the Solvent Extraction of Cesium from Alkaline High-Level Tank Waste. Solvent Extr. Ion Exch. 2003, 21(2), 141-170.

[16] Delmau, L. H.; Bostick, D. A.; Haverlock, T. J.; Moyer, B. A. Caustic-Side Solvent Extraction: Extended Equilibrium Modeling of Cesium and Potassium Distribution Behavior. Report ORNL/TM-2002/116; Oak Ridge National Laboratory, Oak Ridge, TN, May 2002.

[17] Delmau, L. H.; Baes, C. F., Jr.; Bostick, D. A.; Haverlock, T. J.; Moyer, B. A. Solvent Extraction System Modeling Using the Program SXFIT. In Leaching and Solution Purification. Hydrometallurgy 2003-Fifth International Conference in Honor of Professor Ian Ritchie, Vol. 1, Proc. 2003 Int. Symp. Hydrometallurgy, Vancouver, Canada, August 24-27, 2003; Young, C. A., Alfantazi, A. M., Anderson, C. G., Dreisinger, D. B., Harris, B., James, A., Eds.; TMS (The Minerals, Metals, and Materials Society), Warrendale, PA, 2003; pp. 969-981.

[18] Delmau, L. H.; Haverlock, T. J.; Sloop, F. V., Jr.; Moyer, B. A. Caustic-Side Solvent Extraction: Prediction of Cesium Extraction from Actual Wastes and Actual Waste Simulants. Report ORNL/TM-2003/011; Oak Ridge National Laboratory, Oak Ridge, TN, February 2003.

[19] Delmau, L. H.; Bazellaire, E.; Bonnesen, P. V.; Engle, N. L.; Gorbunova, M.; Haverlock, T. J.; Moyer, B. A.; Ensor, D. D.; Meadors, V. M.; Harmon, B. M.; Bartsch, R. A.; Surowiec, M. A.; Zhou, H. Stripping Improvements in Solvent Extraction Processes: Application to the CausticSide Solvent Extraction (CSSX) Process. Proc. Int. Solvent Extraction Conf., ISEC 2008, Tucson, Arizona, September 15-19, 2008; Moyer, B. A., Ed.; Metallurgical Society of CIM, Montreal, Canada, in press. 
[20] Delmau, L. H.; Haverlock, T. J.; Bazellaire, E.; Bonnesen, P. V.; Ditto, M. E.; Moyer, B. A. Alternatives to Nitric Acid Stripping in the Caustic-Side Solvent Extraction (CSSX) Process. Solvent Extr. Ion Exch., submitted.

[21] Engle, N. L.; Bonnesen, P. V.; Tomkins, B. A.; Haverlock, T. J.; Moyer, B. A. Synthesis and Properties of Calix[4]arene-bis[4-(2-ethylhexyl)benzo-crown-6], a Cesium Extractant with Improved Solubility. Solvent Extr. Ion Exch. 2004, 22(4), 611-636.

[22] Keever, T. J.; Bonnesen. P. V. Procedure for Evaluating Optimized CSSX Solvent Quality. Letter Report issued to Parson Engineering, Aiken SC; Oak Ridge National Laboratory, Oak Ridge, TN, Sept. 23, 2005.

[23] Leonard, R. A. Solvent Characterization Using the Dispersion Number. Sep. Sci. Technol. 1995, 30(7-9), 1103-1122.

[24] Haverlock, T. J.; Bonnesen, P. V.; Sachleben, R. A.; Moyer, B. A. Analysis of Equilibria in the Extraction of Cesium Nitrate by Calix[4]arene-bis(t-octylbenzo-crown-6) in 1,2-Dichloroethane. J. Inclusion Phenom. Mol. Recognit. Chem. 2000, 36, 21-37.

[25] Bonnesen, P. V.; Delmau, L. H.; Haverlock, T. J.; Moyer, B. A. Alkaline-Side Extraction of Cesium from Savannah River Tank Waste Using a Calixarene-Crown Ether Extractant. Report ORNL/TM-13704; Oak Ridge National Laboratory, Oak Ridge, TN, December 1998.

[26] Delmau, L. H.; Van Berkel, G. J.; Bonnesen, P. V.; Moyer, B. A. Improved Performance of the Alkaline-Side CSEX Process for Cesium Extraction from Alkaline High-Level Waste Obtained by Characterization of the Effect of Surfactant Impurities. Report ORNL/TM-1999/209; Oak Ridge National Laboratory, Oak Ridge, TN, 1999.

[27] Delmau, L. H.; Bonnesen, P. V.; Moyer, B. A. A Solution to Stripping Problems Caused by Organophilic Anion Impurities in Crown-Ether Based Solvent Extraction Systems: A Case Study of Cesium Removal from Radioactive Wastes. Hydrometallurgy 2004, 72(1,2), 9-19.

[28] Mitchell, A. D. SEPHIS-MOD4; A User's Manual to a Revised Model of the PUREX Solvent Extraction System. Report ORNL-5471; Oak Ridge National Laboratory, May 1979.

[29] Jubin, R. T.; DeMuth S. F.; Singh, S. P. Developments in Centrifugal Contactor Technology. Report ORNL/TM-10768; Oak Ridge National Laboratory, September 1988. 


\section{DISTRIBUTION}

\section{(All distribution electronic)}

\section{INTERNAL}

1. J. F. Birdwell, Jr.

2. P. V. Bonnesen

3. L. H. Delmau

4. S. R. Greene

5. J. McFarland

6. B. E. Lewis, Jr.

7. C. P. McGinnis

8. B. A. Moyer

9. F. V. Sloop, Jr.

10. ORNL Central Research Library

11. Laboratory Records, RC

12. Laboratory Records, OSTI

\section{EXTERNAL DISTRIBUTION}

13. C. Conner, Parsons Engineering, 1080 Silver Bluff Rd., Aiken SC 29803

14. S. D. Fink, Westinghouse Savannah River Company, P.O. Box 616, Building 773-A, Aiken, SC 29808

15. H. D. Harmon, Tank Focus Area Salt Processing Program, P.O. Box 616, Building 704-3N, Aiken, SC 29808

16. M. E. Johnson, CH2M HILL Hanford Group, Inc., Richland WA

17. G. J. Lumetta, Pacific Northwest National Laboratory, P.O. Box 999; MSIN P7-22, Richland, WA 99352

18. M. A. Norato, Westinghouse Savannah River Company, P.O. Box 616, Building 773-A, Aiken, SC 29808

19. P. C. Suggs, U.S. Department of Energy, Savannah River Operations Office, P.O. Box A, Building 704-3N, Aiken, SC 29808 
20. M. C. Thompson, Westinghouse Savannah River Company, P.O. Box 616, Building 773-A, Aiken, SC 29808

21. T. A. Todd, Idaho National Engineering \& Environmental Laboratory, Building 637, MS-5218, Idaho Falls, ID 834415-5218

22. W. R. Wilmarth, Westinghouse Savannah River Company, P.O. Box 616, Building 773-A, Aiken, SC 29808 